\title{
Workplace health promotion and
}

\section{labour market performance of employees}

\author{
Martin Huber ${ }^{+}$, Michael Lechner ${ }^{+}$, Conny Wunsch ${ }^{++*}$ \\ ${ }^{+}$University of St. Gallen, Swiss Institute for Empirical Economic Research (SEW) \\ ${ }^{++}$University of Basel, Department of Labour Economics
}

This draft: June 2014

Date this version has been printed: 27 June 2014

\begin{abstract}
This paper investigates the average effects of (firm-provided) workplace health promotion measures in form of the analysis of sickness absenteeism and health circles/courses on labour market outcomes of the firms' employees. Exploiting linked employer-employee panel data that consist of rich surveybased and administrative information on firms, workers and regions, we apply a flexible propensity score matching approach that controls for selection on observables as well as on time-constant unobserved factors. While the effects of analysing sickness absenteeism appear to be rather limited, our results suggest that health circles/courses increase tenure and decrease the number of job changes across various age groups. A key finding is that health circles/courses strengthen the labour force attachment of elderly employees (51-60), implying potential cost savings for public transfer schemes such as unemployment or early retirement benefits.
\end{abstract}

Keywords: Firm health policies, health circles, health courses, analysis of sickness absenteeism, matching

JEL classification: I10, I19, J32

Addresses for correspondence:

Martin Huber, Michael Lechner: University of St. Gallen, Swiss Institute for Empirical Economic Research (SEW) Varnbüelstrasse 14, CH-9000 St. Gallen, Switzerland, martin.huber@unisg.ch, michael.lechner@unisg.ch, www.michael-lechner.eu .

Conny Wunsch: Department of Labour Economics, Faculty of Business and Economics, University of Basel, Peter-Merian-Weg 6, CH-4002 Basel, Switzerland, conny.wunsch@unibas.ch, http://wwz.unibas.ch/wunsch.

Michael Lechner and Conny Wunsch are also affiliated with CESIfo, Munich, and IZA, Bonn. Michael Lechner has further affiliations with CEPR and PSI, London, and IAB, Nuremberg. This project received financial support from the Institut für Arbeitsmarkt und Berufsforschung, IAB, Nuremberg (contract 8104), and from the St. Gallen Research Center for Aging, Welfare, and Labor Market Analysis (SCALA). We are grateful to the staff of the Forschungsdatenzentrum (FDZ) of the Federal Employment Office (BA) in Nuremberg, where the estimations were conducted, who provided kind and skilful assistance. 


\section{Introduction}

The health of employees is an important cost factor for firms and a key determinant of the productivity of an economy. Although, due to the complexity of the issue, it is difficult to obtain precise and undisputable numbers of direct costs and productivity losses, rough estimates suggest, for example, that the bad quality of the air in US firms alone lead to annual costs of about $250 \mathrm{bn}$. USD due to additional medical expenses and lost productivity. ${ }^{1}$ For Germany, the country we study in this paper, BMAS (2014) estimates that in 2012, with on average 14 work days lost per worker, production losses due to illness amounted to 53 bn. EUR (corresponding to 92 bn. EUR in terms of value added). Although such numbers must be interpreted with care, they show the large potential gains that could be realised by improving employees' health. Thus, it is not surprising that health issues receive considerable attention from national governments, as well as from supranational and international agencies. ${ }^{2}$

Employers are of course also interested in the good health of their workforce. They can influence the health of their employees in two different ways: First, they can provide a workplace that fosters, or is at least not detrimental to, health. Second, they may encourage their employees to pursue a healthier life style in general by providing information, incentives, and opportunities (e.g. courses about healthy eating or subsidies for a fitness centre). Many larger firms follow such strategies and the economic benefits for employers and the positive health effects for employees have been documented extensively in the public health literature. ${ }^{3}$ However, to the best of our knowledge the literature still lacks a thorough investigation of the effects of such measures on future labour market outcomes of employees.

1 See New York Times (2013).

2 An example for the latter at the European level is the European Agency for Safety and Health at Work (OSHA, https://osha.europa.eu/en). At the international level, safety at work is an important topic for the Internal Labour Organization (ILO, http://www.ilo.org/global/topics/safety-and-health-at-work), for example.

3 For an excellent review of the literature see Kreis and Bödeker (2004), which covers 25 high-quality review articles that summarize more than 400 studies, as well as Sockoll, Kramer and Bödeker (2009), which is an update of the earlier survey and covers 40 review articles that summarize more than 1000 studies. 
There are several reasons why this appears important. Firstly, workers with health problems have a higher probability of receiving payments from public transfer systems such as unemployment insurance, welfare schemes or disability insurance because they face a higher risk of becoming (and staying) unemployed as well as of leaving the labour market early (e.g. Böckerman and Ilmakunnas 2009). Therefore, it is of interest for policy makers whether such employer policies reduce dependency rates and if so, whether the effects are sufficiently large to justify their active promotion using public funding. Secondly, reduced turnover due to improved worker-firm matches not only reduces turnover costs for firms, but may also stabilise workers' careers, which has positive effects on lifetime wealth (especially pension wealth) and on contributions to the social insurance system. Finally, health-improving measures adopted by firms may increase the labour market attachment of elderly workers, thus alleviating the negative effects of the demographic change in terms of both shortage of skilled workers and financial strains on the pension system.

It is the objective of this paper to fill this gap. We analyse the impact of selected health promotion measures provided by firms on medium-term labour market outcomes of employees in Germany. Our study is based on unique linked employer-employee data combining administrative records of individual labour market histories with a panel survey of firm establishments and regional statistics. Among many other characteristics, the panel survey contains information about the establishments’ provision of specific health promotion activities. Based on this information, we separately investigate the effects of two classes of measures which have been introduced in firms between 2002 and 2004: (i) systematic analysis of sickness absenteeism in the firm, (ii) courses to improve the health knowledge and health-seeking behaviour of the firms' employees, as well as (iii) so-called health circles where health problems are discussed in groups with the aim of finding ways to alleviate or overcome these problems. The administrative records allow us to assess individual labour market outcomes in terms of employment, unemployment, firm-provided early retirement, inactivity, and turnover from 
mid-2004 to the end of 2008. Furthermore, they also provide individual worker characteristics as well as information about the composition of the establishments' work forces prior to any health promotion, which (in addition to the firm characteristics from the survey and the regional information) can be used to control for selection into these measures.

As with any such study, it is most interesting to estimate the effects of the health interventions on labour market outcomes rather than merely uncovering statistical associations between interventions and outcomes. In the absence of experimental evidence (which is apparently more difficult and expensive to obtain because labour market outcomes take longer to materialize than many health outcomes) or any other exogenous outside variation influencing the establishments' implementation of health promotion measures, our identification strategy has to rely on a different approach. Firstly, we eliminate the potential problem that workers may select themselves into establishments offering health services: On the one hand, we focus on establishments that had no such offerings by mid-2002, thus equalising firms in that respect. On the other hand, we only consider workers who entered the respective establishments at least two years prior to mid-2002. Secondly, by conditioning on a rich set of firm, worker, and regional characteristics coming from the various data sources, we account for the selective introduction of such measures in some firms between 2002 and 2004. Thirdly, since we are interested in individual labour market outcomes of employees, we use the panel structure of the data and take-out unobserved factors and differential trends that determine labour market performance by conditioning on long-run pre-implementation labour market outcomes. Some placebo-like tests implicit in our results support our strategy.

Our results suggest that the investigated health promotion activities have mixed effects on employees' labour market outcomes. Analysing sickness absenteeism, an intervention that only passively involves the employees, is found to have a rather limited impact. This measure is merely found to somewhat reduce the number of employer changes of younger and mid- 
aged workers after 3-4 years. In contrast, health courses and health circles, which activate employees directly, increase tenure in the studied firm and reduce overall turnover among all age groups. Moreover, for older workers, who are most likely to suffer from health problems and are thus of particular interest, the measures strengthen labour market attachment. They significantly increase employment by reducing unemployment and thereby dependence on unemployment insurance payments, as well as by reducing exits from the labour market via a specific type of firm-provided early retirement scheme. Thus, besides the beneficial effects on firms and employees’ health documented in the previous literature, there also seem to be additional benefits in the longer run for both employees and social insurance systems.

The paper proceeds as follows: In the next section, we briefly describe several aspects of the health policies of German firms. Section 3 is devoted to data and measurement issues and provides selected descriptive statistics. Section 4 contains the discussion of the identification strategy and presents the estimator used. Section 5 empirically characterises the establishments implementing the different measures and presents the estimated effects for the health promotion activities considered in this paper. Section 6 concludes. Appendix A contains extensive descriptive statistics, while Appendix B contains additional results omitted from the main body of the paper.

\section{Firms' health policies in Germany}

The Initiative for Health and Work (Initiative für Gesundheit und Arbeit, IGA) provides a summary of legally required and voluntarily provided measures of German firms to ensure and improve the safety and health of employees at their workplace (IGA, 2009). Our study focuses on voluntary measures that we will describe in more detail in the following. With one exception, the German measures are largely comparable to those of other counties. ${ }^{4}$ Com-

\footnotetext{
4 See the compilation of measures on http://www.enwhp.org/european-toolbox.html.
} 
prehensive and internationally comparable data on the use of health promotion measures at the work place is, unfortunately, rare. One of the few data sources that provide at least some information is the European Survey of Enterprises on New and Emerging Risks, which has been conducted by the European Agency for Safety and Health at Work in 2009.

Figure 2.1: Share of establishments answering 'yes' to various questions about workplace health promotion in 2009 by country and establishment size
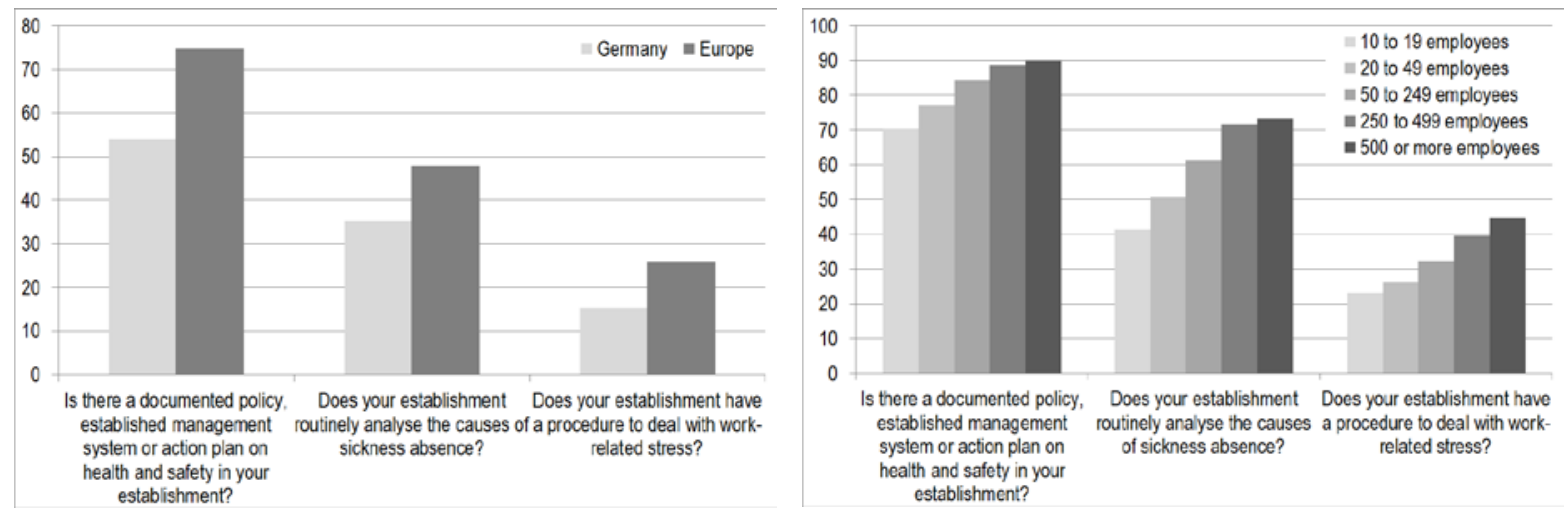

Source:Own graph based on data from the European Survey of Enterprises on New and Emerging Risks (ESENER) 2009. Data was retrieved from https://osha.europa.eu/sub/esener/en/front-page on June 12, 2014. The right panel uses the data from all 31 European countries included in the survey.

The left panel of Figure 2.1 shows the share of establishments that implemented different health and safety procedures in Germany and Europe. 54\% of German and 75\% of European establishments have at least some formalized health and safety procedure, $35 \%$ of German, and 50\% of European establishments routinely analyse sickness absenteeism and, respectively, $15 \%$ and $26 \%$ have some procedure to deal with work-related stress. Moreover, the right panel of Figure 2.1 shows that the prevalence of the measures quite strongly increases with establishment size with differences of 20-30 percentage points between the smallest and the largest firms.

The measures most frequently adopted by German firms coincide with the ones surveyed in the IAB Establishment Panel, which is a representative survey of establishments ${ }^{5}$ in

\footnotetext{
5 An establishment is either a single firm, or comprises all branches of a larger firm within the same relatively narrowly defined region and industry. In the following, we will use the terms establishment and firm interchangeably.
} 
Germany and also part of the data we use. Questions about health promoting activities of firms were included in the 2002 and 2004 questionnaires. The shares of establishments that offer a respective health measure are displayed in Table 2.1 for both years.

Table 2.1: Share of establishments offering different health policies implemented by firms in the IAB Establishment Panel 2002 and 2004

\begin{tabular}{lcc}
\hline \hline Health measure & 2002 & 2004 \\
\hline Analysis of sickness absenteeism & $30 \%$ & $29 \%$ \\
Surveys of employees about health risks at the workplace & $19 \%$ & $18 \%$ \\
Discussion groups about health problems in the workplace (health circles) & $10 \%$ & $9 \%$ \\
Courses about healthy behaviour & $14 \%$ & $15 \%$ \\
Other than the above mentioned & $12 \%$ & $10 \%$ \\
\hline None of the above & $54 \%$ & $56 \%$ \\
\hline Missing information & $0.5 \%$ & $0.4 \%$ \\
\hline Total number of observations & 15682 & 16063 \\
\hline Note: Multiple answers are possible. See Appendix C for the question underlying this table.
\end{tabular}

With about $30 \%$ of establishments using it, the most popular measure is a systematic analysis of sickness absenteeism in the firm. Because of reporting requirements, most firms have some records on sickness absenteeism and a significant share of them uses these data to gain knowledge about potential problems and possible solutions. To do so, firms analyse the incidence of absenteeism, average duration, causes, systematic patterns, and the characteristics of the absentees and often compare their numbers to other businesses in the same industry (IGA, 2009). Secondly, to collect information on health risks and mental or physical pressures experienced or perceived by employees as well as potential complaints almost $20 \%$ of firms conduct anonymous employee surveys (IGA, 2009). About 15\% of firms offer health courses that comprise talks and lectures to advise workers on health issues such as a healthy working position, healthy eating or drug use, learning exercises to improve, for example, back muscles. Furthermore, there are relaxation courses, courses for people who want to give up smoking, and so on (IGA, 2009). About 10\% of establishment make use of so-called health circles, which are a particularity of the German system. These are discussion groups where employees and sometimes supervisors collect information about work-related health prob- 
lems, stress or psychological pressures, and their causes and discuss possible solutions. Usually, a health circle is set up for a limited period (6-10 meetings) and followed by the creation of a within-firm working group of employees, which seeks to implement improvements (IGA, 2009). $10-12 \%$ of firms also use a variety of other measures such as free access to or subsidies for fitness clubs, health days, and sports events. Finally, about $55 \%$ of establishments do not offer any health promotion measures.

\section{Data and definition of the sample}

\subsection{Data}

Our empirical analysis relies on unique linked employer-employee data that combine different administrative and survey data sets from the Federal Employment Agency's Institute of Employment Research (IAB). The data is based on the IAB Establishment Panel, which is a representative survey of German establishments. It covers a broad spectrum of firm level information including firm size, industry, legal form, biographical data, structure of the work force (e.g. education, occupation, share of males/females), employee turnover, vacancies and labour demand, working hours, and human resource policies (e.g. flexible work time, inclination to recruit older workers). Furthermore, there is information on training activities, financial revenues and profits, investment activities, usage rate, technological and organizational factors, and use of financial support or subsidies, among many others. The survey was first conducted in 1993 and is annually repeated. It is an unbalanced panel due to attrition and the inclusion of new companies over time.

The information from the IAB Establishment Panel has been merged with the so-called IAB Establishment History Panel that includes a rich set of aggregate information on the firm's employees. The variables describe the composition of a firm's work force, for example in terms of age, education, tenure, and earnings. They are based on the employees' social in- 
surance records and are constructed, for each year, from the cross section of all workers employed in the firm on June 30.

For the firms in our sample, described in more detail below, the social insurance records of their employees for the years 1990-2008 were merged to the firm data. They comprise employment, unemployment and earnings histories, as well as a rich set of personal characteristics for all workers employed by the firms in our data on June 30, 2002. The social insurance records have also been used, for example, by Wunsch and Lechner (2008), Biewen et al. (2013), Wunsch (2013), and Lechner and Wunsch (2013), with a different sampling design, though. Finally, the data also contain a rich set of regional characteristics, merged via county identifiers from regional statistics, such as the federal state, urbanization, and local labour market conditions.

\subsection{Selection of the sample and definition of treatments}

Our empirical analysis is based on a subsample of the establishments included in the IAB Establishment Panel (IAB-EP) in 2002. For this project, we had access to a linked employer-employee dataset that covers 2,819 of the 15,682 establishments in the 2002 wave of the IAB-EP. Excluded are establishments with less than 100 employees (about $75 \%$ of all 2002 firms), the 25 largest firms, and firms in the sectors agriculture, foresting, mining, energy, transportation, messaging, education and social insurance (about 20\% of all 2002 firms). ${ }^{6}$ For design purposes, we focus on estimating the effects of the introduction of workplace health promotion measures between mid-2002 and mid-2004. This requires, firstly, that we are able to measure the use of these measures both in 2002 and in 2004. Due to relatively high attrition rates in the IAB-EP and a small amount of item non-response, this reduces the original sample by $30 \%$. Secondly, firms that already offered health promotion measures in

\footnotetext{
6 This paper is part of a larger cooperation project with the IAB, which focused on intra-firm comparisons of workers in the primary and tertiary private sector. The former required a sufficiently large numbers of employees per firms. For the latter, sectors with large public shares in the past were excluded as well.
} 
mid-2002 are also excluded. This affects a relatively large number of firms, but is essential for identification as we discuss in detail below. ${ }^{7}$ To avoid common support problems, we also exclude firms in East Germany and Berlin (14\%), as well as establishments with more than 800 employees (32\%), with more than $10 \%$ of temporary workers $(0.8 \%)$, or firms indicating 'problems because their work force is too old' (3\%), as these characteristics almost perfectly predict whether firms offer health promotion measures in 2004. Hence, firms with and without such measures cannot be 'made comparable’ with respect to these characteristics.

Our analysis is concerned with the individual-level outcomes of the employees of the firms in our sample. We only consider workers of age 31 to 60 years (in June 2002). This condition ensures that workers are sufficiently distant to educational choices and statutory retirement age (65). As one may suspect that health promotion activities have different effects on younger and older workers (because the former are in general less subject to health problems), we conduct the empirical analysis within three age-specific strata (31-40, 41-50, 5160). For design purposes, explained below, we also exclude workers with less than 2 years of tenure with their employer.

As already mentioned in Section 2, the information about the different health promotion activities comes from the 2002 and 2004 waves of the IAB-EP. Establishments were asked to state which type of health promotion they implemented or supported, or whether they did not implement or support any such measure (see Appendix C for the exact survey question). For reasons of sample size and homogeneity, we group establishments into three so-called 'treatments' based on this information. The first group of establishments indicated to analyse sickness-related absenteeism. We use the short-cut SickAna for this intervention. The second

\footnotetext{
Table A.1 in Appendix A contains cross tabulations of the answers to the questions about the use of health promotion measures in 2002 and 2004 for all establishments that participated in the 2002 and in the 2004 waves of the IAB Establishment Panel, have non-missing entries for the respective question, and are part of the linked-employer-employee data used in this project. It shows the numbers of establishments that are relevant for the empirical analysis before removing firms with at least one measure in 2002 and before applying further restrictions to ensure common support.
} 
group consists of establishments that introduced health circles and/or health courses (Courses) for their employees. In this group, 23\% of establishments offered health circles, $91 \%$ health courses, and 14\% implemented both measures. It should be noted that, unfortunately, it is unknown whether individual workers actually participate in Courses. It appears reasonable to assume that participation in Courses has an effect at least as large as the mere offer of such an opportunity (which may or may not be taken up). Hence, the estimated effect of the offer represents a lower bound on the effect of actual participation of workers. Note that the first and second groups may overlap to some extent: $35 \%$ of the establishments offering Course also used SickAna. Of those implementing SickAna, 9\% offered health circles and 23\% health courses. Unfortunately, sample size considerations prevent us from analysing the other options mentioned in the survey (see Table 2.1 ), ${ }^{8}$ or from analysing courses and health circles separately. Finally, the third group (the control group or so-called 'non-treated') consists of establishments that did neither implement nor support any health measure and does therefore not overlap with SickAna or Course. The resulting sample sizes of firms and workers for each stratum and treatment are displayed in Table 3.1.

Table 3.1: Number of firms and individuals per stratum

\begin{tabular}{cccc|ccc}
\hline \hline Health measure & \multicolumn{2}{c|}{ Analysis of sickness absenteeism } & \multicolumn{3}{|c}{ Health circles/courses } \\
Age & $31-40$ & $41-50$ & $51-60$ & $31-40$ & $41-50$ & $51-60$ \\
\hline Number of firms & 163 & 162 & 163 & 197 & 196 & 197 \\
Number of workers & 11227 & 11323 & 7670 & 9693 & 10124 & 6732 \\
\hline
\end{tabular}

\subsection{Descriptive statistics}

Table 3.2 contains a first description of the data in terms of the means of selected variables by age stratum and treatment status. ${ }^{9}$ The four upper panels describe the underlying

8 The alternative of grouping them together with either SickAna or Course would lead to a very heterogeneous group of measures. The estimated effects for such a group would be very difficult to interpret.

9 A more extensive set of descriptive statistics can be found in Tables A.2 and A.3 in Appendix A. Due to the very large number of variables in the data (several hundred) we abstain from presenting statistics on all variables. They are available on request. The information available in the administrative data is well documented in Wunsch and Lechner (2008) and 
population of workers and establishments prior to treatment in June 2002. The lower panel contains outcome variables measured from July 2004 to December 2008.

Establishments that offer health courses and/or health circles are quite distinct from the other establishments. On average, they are larger and employ more women. This coincides with higher shares of part-time employment and lower shares of firms active in manufacturing. They also operate under more difficult economic circumstances, with lower regional GDP growth rates, fewer jobs per inhabitant, and lower investments per employee. In contrast, firms that analyse sickness absenteeism are quite similar to firms that do not offer any health promotion measures. Somewhat larger differences only occur with respect to the share of establishments in the manufacturing sector, which is lower for the latter firms, and investments per employee, which is are higher.

Concerning potential reasons for introducing health promotion measures, it is interesting to see that fewer firms who state to have problems with high absenteeism introduce health promotion measures. Instead, there is a positive correlation between the introduction of such measures and having a work council, i.e. a formal representation of employees in the firm, as well as having difficulties to hire skilled workers. The latter seems to suggest that health promotion measures may have been introduced by firms to be more attractive for skilled workers. Also interesting from the point of potential selection problems is the observation that the labour market performance of a firm's employees prior to treatment is very similar for all treatment groups and hence, seems to be unrelated to whether or not firms introduce health promotion measures at the work place. This suggests that by limiting our sample to workers with at least 2 years of tenure in the studied firms before potential treatment we largely succeeded in eliminating bias due to self-selection of workers into firms.

Lechner and Wunsch (2013). For a detailed documentation of the variables available in the IAB Establishment Panel, see http://fdz.iab.de/de/FDZ_Establishment_Data/IAB_Establishment_Panel/IAB_Establishment_Panel_Working_Tools.aspx and for those in the IAB Establishment History Panel see http://fdz.iab.de/de/FDZ_Establishment_Data/ Establishment_ History_Panel/Establishment_History_Panel_Working_Tools.aspx . 
Table 3.2: Selected descriptive statistics by stratum and treatment status

\begin{tabular}{|c|c|c|c|c|c|c|c|c|c|c|}
\hline \multicolumn{2}{|l|}{$\begin{array}{ll}\text { Age in } 2002 \text { (stratum) } \\
\end{array}$} & \multicolumn{3}{|c|}{31 to 40} & \multicolumn{3}{|c|}{41 to 50} & \multicolumn{3}{|c|}{51 to 60} \\
\hline \multicolumn{2}{|l|}{ Health measure (treatment) } & None & $\begin{array}{l}\text { Sick- } \\
\text { Ana }\end{array}$ & $\begin{array}{l}\text { Cour- } \\
\text { se }\end{array}$ & None & $\begin{array}{l}\text { Sick- } \\
\text { Ana }\end{array}$ & $\begin{array}{l}\text { Cour- } \\
\text { se }\end{array}$ & None & $\begin{array}{l}\text { Sick- } \\
\text { Ana }\end{array}$ & $\begin{array}{l}\text { Cour- } \\
\text { se }\end{array}$ \\
\hline & & \multicolumn{9}{|c|}{ Establishment characteristics } \\
\hline \multirow{2}{*}{\multicolumn{2}{|c|}{$\begin{array}{l}\text { Manufacturing sector } \\
\text { Number of employees }\end{array}$}} & 0.46 & 0.62 & 0.29 & 0.47 & 0.58 & 0.25 & 0.43 & 0.58 & 0.27 \\
\hline & & 301 & 304 & 361 & 304 & 301 & 372 & 298 & 310 & 364 \\
\hline \multirow{3}{*}{\multicolumn{2}{|c|}{$\begin{array}{l}\text { Problems with high absenteeism } \\
\text { Difficulties hiring skilled employees } \\
\text { Firm has a works council }\end{array}$}} & 0.13 & 0.09 & 0.10 & 0.13 & 0.11 & 0.10 & 0.11 & 0.10 & 0.09 \\
\hline & & 0.35 & 0.39 & 0.44 & 0.33 & 0.38 & 0.46 & 0.33 & 0.38 & 0.51 \\
\hline & & 0.80 & 0.86 & 0.89 & 0.84 & 0.87 & 0.91 & 0.86 & 0.89 & 0.90 \\
\hline \multicolumn{2}{|c|}{ Investment per employee $/ 10000$} & 0.75 & 0.68 & 0.35 & 0.77 & 0.72 & 0.33 & 0.74 & 0.65 & 0.30 \\
\hline & & \multicolumn{9}{|c|}{ Individual characteristics of employees (shares) } \\
\hline \multirow{3}{*}{\multicolumn{2}{|c|}{$\begin{array}{l}\text { Women } \\
\text { Part-time employed } \\
\text { No vocational degree }\end{array}$}} & 0.39 & 0.37 & 0.49 & 0.42 & 0.44 & 0.55 & 0.44 & 0.43 & 0.52 \\
\hline & & 0.17 & 0.15 & 0.24 & 0.19 & 0.18 & 0.28 & 0.25 & 0.22 & 0.30 \\
\hline & & 0.16 & 0.17 & 0.09 & 0.22 & 0.18 & 0.12 & 0.22 & 0.18 & 0.15 \\
\hline \multirow{3}{*}{\multicolumn{2}{|c|}{$\begin{array}{l}\text { Jobs per inhabitant aged } 15-64 \\
\text { GDP growth } 1994 \text { to } 2002 \text { in } \%\end{array}$}} & \multicolumn{9}{|c|}{ Regional characteristics } \\
\hline & & 1.2 & 1.0 & 0.8 & 1.1 & 1.2 & 0.7 & 1.4 & 1.2 & 0.7 \\
\hline & & 23 & 22 & 19 & 24 & 22 & 19 & 23 & 22 & 19 \\
\hline \multicolumn{11}{|c|}{ Pre-treatment outcomes (individual level) } \\
\hline \multirow{3}{*}{\multicolumn{2}{|c|}{$\begin{array}{l}\text { Share employed in past } 10 \text { years } \\
\text { Share unemployed in past } 10 \text { years } \\
\text { Share inactive in past } 10 \text { years }\end{array}$}} & 0.87 & 0.85 & 0.85 & 0.92 & 0.92 & 0.90 & 0.94 & 0.95 & 0.94 \\
\hline & & 0.02 & 0.02 & 0.03 & 0.02 & 0.02 & 0.02 & 0.01 & 0.01 & 0.01 \\
\hline & & 0.02 & 0.02 & 0.02 & 0.01 & 0.01 & 0.01 & 0.01 & 0.01 & 0.01 \\
\hline & \multicolumn{9}{|c|}{ Outcome variables (individual level) } \\
\hline & $2 / 2004$ & 5.5 & 5.6 & 5.7 & 5.6 & 5.6 & 5.7 & 5.0 & 5.0 & 5.1 \\
\hline employed until end of & $2 / 2008$ & 48.7 & 49.3 & 49.5 & 48.6 & 49.1 & 49.9 & 36.4 & 37.1 & 38.3 \\
\hline \multirow{2}{*}{$\begin{array}{l}\text { Cum. months in early ret. } \\
\text { scheme } 10 \text { until end of }\end{array}$} & $2 / 2004$ & 0.0 & 0.0 & 0.0 & 0.0 & 0.0 & 0.0 & 0.7 & 0.7 & 0.6 \\
\hline & $2 / 2008$ & 0.0 & 0.0 & 0.0 & 0.1 & 0.1 & 0.1 & 6.3 & 5.5 & 7.1 \\
\hline \multirow{2}{*}{$\begin{array}{l}\text { Cum. months unemployed } \\
\text { until end of }\end{array}$} & $2 / 2004$ & 0.2 & 0.2 & 0.1 & 0.3 & 0.2 & 0.1 & 0.4 & 0.4 & 0.2 \\
\hline & $2 / 2008$ & 1.8 & 1.8 & 1.2 & 2.3 & 2.0 & 1.5 & 4.2 & 3.7 & 2.4 \\
\hline \multirow{3}{*}{\multicolumn{2}{|c|}{$\begin{array}{ll}\begin{array}{l}\text { Number of employer } \\
\text { changes until end of }\end{array} & 2 / 2004 \\
2 / 2008\end{array}$}} & 0.0 & 0.0 & 0.0 & 0.0 & 0.0 & 0.0 & 0.0 & 0.0 & 0.0 \\
\hline & & 0.2 & 0.2 & 0.1 & 0.2 & 0.1 & 0.1 & 0.1 & 0.1 & 0.1 \\
\hline & & 4.9 & 5.2 & 5.2 & 5.1 & 5.4 & 5.5 & 4.2 & 4.5 & 4.6 \\
\hline \multicolumn{2}{|c|}{ \# of employees (observations) } & 6247 & 4858 & 3312 & 6613 & 4622 & 3420 & 4366 & 3073 & 2135 \\
\hline
\end{tabular}

Note: Statistics are based on the samples used for estimation. If not explicitly mentioned otherwise, variables are measured in 2002. 1/200x denotes the first half of the 200x, while 2/200x denotes the second half of this year. For all cumulated measures, accumulation begins in 2/2004.

In terms of outcome variables, the differences between the three groups of firms are mostly small. Somewhat larger differences are mainly visible for the elderly who exhibit more time in employment and less time in unemployment if employed in firms that offer health courses and/or circles rather than in firms that do not offer any health promotion measures.

10 The administrative records allow measuring one specific type of firm-provided early retirement scheme, which is called "Altersteilzeit" in German. Workers who want to retire early sign a 6-year contract with the firm. They either work fulltime at a reduced wage for 3 years and then stop working but continue to receive the same wage for 3 more years (socalled block model, which is by far the most common case), or they work part-time at a reduced wage for the full 6-year period. In both cases, workers are recorded in the data for the full 6-year period. Eligibility starts at age 55. 
This might be suggestive of a positive effect of these measures in this age group. In the econometric analysis below, we will assess whether this is indeed the case.

\section{Empirical strategy}

\subsection{Identification}

We are interested in the effects of a firm offering a certain type of workplace health promotion measure compared to not offering any such measure on the labour outcomes of the firm's employees. To disentangle these effects from other determinants of the worker's labour market outcomes, two selection problems need to be solved. Firstly, workers may self-select into firms that offer certain health promotion measures. We approach this problem by focusing on firms that did not offer any such measure by mid-2002 and by only considering workers who have been with the firm for at least 2 years by mid-2002. Hence, all workers we include in the analysis joined the firms at a point in time when they did not offer, and it was not foreseeable that they will offer, any health promotion measure.

The second selection problem arises because firms selectively rather than randomly introduced health promotion measures between mid-2002 and mid-2004. This also became visible when comparing the characteristics of the firms across treatment states in Section 3.3. To solve a large part of this problem, we exploit that the data are very informative and allow us to capture most of the potential drivers of the decision to introduce health measures and of workers’ labour market outcomes (so-called ‘confounders').

From a theoretical perspective, taking the view of a profit maximising enterprise, health promotion measures should be introduced if they are cost-effective. Firm performance, which also depends on the economic situation in the region and industry, is one of the most obvious factors because it affects the financial means available for costly health promotion. Firm size appears to be an important determinant of health promotion costs per employee, given that 
introductory fixed costs, e.g. for building up the infrastructure, are non-negligible. The potential returns from these measures depend on health risks that differ a lot by industry and occupation but also by individual characteristics, such as education and age, because of different health knowledge and health investments. They also depend on health problems evident in the firm such as high absenteeism and high accident rates. Finally, the bargaining power of employees may play an important role in introducing health promotion measures. A strong representation of workers' interest, e.g. via a works council in the firm or strong unionization, is more likely to enforce better working conditions. All of these factors (that determine the firms' decision to engage in health promotion activities) are likely to affect individual workers' labour market outcomes as well. Thus, they need to be controlled for.

The importance of these factors is also confirmed by several empirical studies, mostly in the public health literature, which have investigated the relationship between firm characteristics and health promotion. Kenkel and Supina (1992) analyse data from the US National Survey of Worksite Health Promotion Programs and find that firm size, the share of females, and corporate health insurance plans are positively correlated with health promotion, while employee turnover is negatively associated with the latter. Based on the same data, Fielding and Piserchia (1989) conclude that health promotion activities also vary with industry and region. Due to different institutional settings with respect to health policies in the US and Germany, the results of studies using German data appear particularly relevant in our context. Ulmer and Gröben (2005) use a survey of firms in the German states of Hessia and Thuringia and find that firm size, the number of work accidents, and profit expectations are significantly associated with health promoting activities. Hollederer (2007) uses the unrestricted version of the IAB Establishment Panel and concludes that health promotion varies considerably with federal states, industry, firm size, and the presence or absence of a works council. Based on a phone survey among German insurance companies, Köhler et al. (2009) argue that firm size and particular firm policies, such as human resources and organizational development 
policies, are related to health promotion. Finally, Jung et al. (2012) investigate the relationship between firm characteristics and the attitude towards health promotion in a survey among German information and communication technology companies. They find a firm's market position and the percentage of employees with an academic education to be associated with a positive attitude towards health promotion among small companies.

Table 4.1 summarizes the factors identified above from the theoretical considerations and the empirical literature and indicates how we can capture them with our data. However, two factors we cannot capture: The first one is the availability of health insurance plans. However, this is not relevant in the German context because health insurance is compulsory for everyone. The second missing factor is related to accidents at work. This is only captured indirectly by controlling for industry, occupation, and the share of employment contracts in the last 10 years that ended due to prolonged illness of more than 6 weeks. These factors are very likely to be strongly correlated with the rate of accidents. They represent potentially important confounders per se.

To address the issue of any potentially remaining unobserved factors and differential trends that drive workers' labour market outcomes, either via their current or past employers or other individual factors, we additionally exploit the panel structure of the data which allows us to observe at least 10 years of detailed pre-treatment labour market outcomes for all workers in our sample. By conditioning on a variety of summary measures of the workers' labour market performance over the 10 years prior to mid-2002, we not only take out any time-constant unobserved factors (fixed effects) that drive labour market outcomes, but also any differential long-term trends. The latter is so because we essentially 'equalize' workers in terms of all kinds of dimensions of labour market performance over the 10 years prior to mid-2002.

The exact specification we use for selection correction is described in the next section and summarized in the last column of Table 4.1. 


\section{Table 4.1 Summary of potential confounders and control variables available in the data}

\begin{tabular}{ccc}
\hline \hline Potential confounders & Variables available in the data & Variables included in the estimation \\
\hline Firm performance & $\begin{array}{c}\text { Total revenues, evaluation of the business } \\
\text { situation, investments per employee, age of firm, } \\
\text { use of government subsidies, establishment is } \\
\text { single firm }\end{array}$ & $\begin{array}{c}\text { Investments per employee, age of firm, } \\
\text { indicator for no use of government sub- } \\
\text { sidies, establishment is single firm }\end{array}$ \\
\hline
\end{tabular}

\begin{tabular}{|c|c|c|}
\hline Firm size & Firm size & Firm size \\
\hline Industry of the firm & Industry of the firm & Industry of the firm \\
\hline Occupation of the employees & Occupation of the employees & Occupation of the employees \\
\hline Turnover & $\begin{array}{c}\text { Distribution of tenure in firm, number of entries } \\
\text { and exits over last year, tenure of individual } \\
\text { employees }\end{array}$ & Tenure of individual employees \\
\hline Strong worker representation & $\begin{array}{l}\text { Indicators for whether firm has works council, is } \\
\text { subject to sectorial or firm-specific wage con- } \\
\text { tract, follows sectorial wage contract or is not } \\
\text { subject to a wage contract }\end{array}$ & $\begin{array}{c}\text { Indicators for whether firm has works } \\
\text { council or is subject to sectorial wage } \\
\text { contract }\end{array}$ \\
\hline
\end{tabular}

\begin{tabular}{|c|c|c|}
\hline $\begin{array}{l}\text { Region and its economic } \\
\text { situation }\end{array}$ & $\begin{array}{l}\text { Region dummies, unemployment rate, migration, } \\
\text { commuting, dummies for urban and rural areas, } \\
\text { population density, GDP growth, jobs per inhab- } \\
\text { itant aged } 15-64 \text {, earnings per capita }\end{array}$ & $\begin{array}{l}\text { Region dummies, GDP growth, jobs per } \\
\text { inhabitant aged 15-64 }\end{array}$ \\
\hline $\begin{array}{l}\text { Composition of the firm's } \\
\text { workforce/ individual char- } \\
\text { acteristics of employees }\end{array}$ & $\begin{array}{c}\text { Gender, age, education, nationality, part- } \\
\text { time/full-time, earnings distribution, occupations, } \\
\text { blue-collar/white-collar job }\end{array}$ & $\begin{array}{l}\text { Gender, age, education, forigner status, } \\
\text { part-time/full-time, earnings, occupation }\end{array}$ \\
\hline Firm policies & $\begin{array}{c}\text { Dozens of variables measuring various human } \\
\text { resource policies, restructuring activities, organi- } \\
\text { zational factors }\end{array}$ & $\begin{array}{l}\text { Firm has difficulties hiring skilled em- } \\
\text { ployees, firm uses working time ac- } \\
\text { counts }\end{array}$ \\
\hline Absenteeism & $\begin{array}{c}\text { Firm states to have problems with high absen- } \\
\text { teeism }\end{array}$ & $\begin{array}{l}\text { Firm states to have problems with high } \\
\text { absenteeism }\end{array}$ \\
\hline Number of work accidents & - & $\begin{array}{l}\text { Industry of the firm, occupation of the } \\
\text { employees, share of employment con- } \\
\text { tracts in the last } 10 \text { years that ended due } \\
\text { to prolonged illness of more than } 6 \\
\text { weeks }\end{array}$ \\
\hline $\begin{array}{l}\text { Corporate health insurance } \\
\text { plans }\end{array}$ & - & $\begin{array}{l}\text { Not relevant in the German context } \\
\text { because of compulsory health insurance } \\
\text { for everyone }\end{array}$ \\
\hline $\begin{array}{l}\text { Other factors and differential } \\
\text { trends }\end{array}$ & $\begin{array}{l}\text { More than } 200 \text { variables with half-yearly meas- } \\
\text { urements of different types of employment, } \\
\text { unemployment, receipt of unemployment insur- } \\
\text { ance, wage earnings, program participation and } \\
\text { inactivity; average duration and number of spells } \\
\text { of employment/unemployment/program partici- } \\
\text { pation/inactivity, over the last } 10 \text { years }\end{array}$ & $\begin{array}{l}\text { Fraction of time employed/unemployed/ } \\
\text { inactive in past } 10 \text { years }\end{array}$ \\
\hline
\end{tabular}

\subsection{Estimation}

Any estimator which eliminates selection based on observed factors is built on the idea of comparing outcomes across units with and without treatment that are similar with respect to observed confounders in order to pin down the causal effect of the treatment. Instead of 
using parametric OLS, we apply a propensity-score-matching estimator that defines similarity in terms of a function of the probability to be treated conditional on the confounders. In the program evaluation literature, this conditional probability is referred to as propensity score (see Rosenbaum and Rubin, 1983). An advantage of these estimators is that they are semiparametric and therefore more robust than parametric methods like OLS, and that they allow for flexible effect heterogeneity (see Huber, Lechner and Wunsch, 2011, for an application in health economics).

We use radius matching on the propensity score with regression adjustment as suggested in Lechner, Miquel, and Wunsch (2011) to estimate the average effects of the two measures relative to 'no such measure'. This estimator is more precise than nearest neighbour matching (e.g. Dehejia and Wahba, 2002), remains consistent if either the matching step is based on a correctly specified propensity score model, or the regression model is correctly specified (so-called double robustness property, see e.g. Rubin, 1979, Joffe et al., 2004), reduces small sample as well as asymptotic biases of matching (Abadie and Imbens, 2006), and appears to perform well in finite samples, also compared to OLS (Huber, Lechner, and Wunsch, 2013), but without having to rely on functional form assumptions.

To obtain the propensity scores required for selection correction, we estimate 6 separate probit models, one for each measure considered, SickAna and Course, and each of the 3 age strata. The dependent variable in any subsample is zero for workers in firms without any health measure and one otherwise (if the respective health measure is provided). All probit models and their results are presented in Appendix B.1. The specifications result from the identification issues discussed above as well as extensive specification tests for normality, heteroscedasticity and in particular omitted variables. The data contain hundreds of variables, a lot of them being highly correlated. We started with a parsimonious specification that included the most important potential confounders according to the empirical literature and the- 
oretical considerations summarized in Table 4.1. Based on omitted variables tests for all variables in the data, we sequentially added additional variables if suggested by the test statistics.

The final specifications include gender, age, foreigner status, wages, tenure in June 2002, and indicators for part-time work, education, and occupation to capture the main determinants of workers' labour market performance as well as occupational health risks. Additionally, we include three summary measures of labour market performance in the past 10 years as pre-treatment outcomes to take out any other time constant unobserved factors that affect workers' labour market performance. We also include regional indicators and two variables capturing regions' economic performance as additional determinants of both individual labour market performance and firm performance where the latter may affect the financial means available to introduce health promotion measures. This is also true for firms' age, size and investments per employee as well as an indicator for establishments that do not use any government subsidies or represent a single firm. To capture health risks and other incentives to introduce health promotion measures, we finally include indicators for the industry, for firms stating to have problems with high absenteeism or difficulties hiring skilled workers, for having a works council or being subject to a sectorial wage contract, and the share of employment contracts in the past 10 years that ended due to prolonged illness of the employee.

Based on the estimated propensity scores, we ensure overlap of the distributions of the covariates in the treated and nontreated samples by excluding treated individuals with scores higher than the maximum among the nontreated and, similarly, nontreated individuals with scores lower than the minimum among the treated. Applying the matching technique outlined above on the common support results in very satisfactory balancing of the covariate distributions across treated and untreated establishments. This holds not only for the variables entering the respective propensity score specifications, but also for variables not explicitely 
included, in particular the large number of workers' pre-treatment labour market outcomes and firm characteristics. ${ }^{11}$

\subsection{Inference}

P-values to test whether the estimated effects are different form zero are obtained from a block bootstrap that resamples establishments (rather than individuals) along with all their employees to account for clustering at the establishment level. ${ }^{12}$ We use 499 bootstrap replications and compute the bootstrap t-statistics of the respective average effects in each of the samples (recentered by the estimated effect in the original sample). We then estimate the pvalue as the share of absolute bootstrap t-statistics that are larger than the absolute t-statistic in the original sample. ${ }^{13}$

\section{Results}

The individual administrative records allow computing a large number of outcome variables, which measure different dimensions of employees' labour market performance from July 2004 to December 2008 (see Table A.2 in Appendix A for a comprehensive list of all variables). With one exception, they are measured in the second half of June or December of a given year, either as binary labour market status indicators or income measures for that particular period, or as half-months in a given labour market status or income from a given

11 Due to the very large number of tested variables, we abstain from presenting the results of the balancing tests. They are available on request.

12 Abadie and Imbens (2008) show that for standard matching (based on a fixed number of comparison observations) bootstrap-based inference may be invalid. However, our matching algorithm is smoother than the one studied by Abadie and Imbens (2008) because it uses a variable number of (distance-weighted) comparisons and a regression adjustment. For this reason, the bootstrap is most likely a valid inference procedure in our context.

13 See for instance MacKinnon (2006) for a discussion on bootstrapping symmetric statistics. Since the theoretical results by Abadie and Imbens (2006) and the simulation based results in Huber, Lechner, and Wunsch (2013) suggest that the estimator is asymptotically normally distributed, bootstrapping the potentially pivotal t-statistic (computed under the assumption that the weights obtained to compute the control group are non-stochastic; see Lechner, 2002) has the advantage of potentially providing so-called asymptotic refinements and thus improving inference. In addition we also checked the bootstrap distribution of the estimated effects, rather than the t-statistics. The results are similar (available on request). 
source accumulated since July $2004 .{ }^{14}$ In the following, we present the results for selected outcomes, which we consider the most interesting. They include two measures of turnover, namely tenure in the studied firm and the number of individual employer changes, as well as the cumulated number of months in employment, unemployment, or in the firm-provided early retirement scheme (described in footnote 10 above).

Below we report the so-called average treatment effect (ATE) of introducing SickAna or Courses compared to not introducing any measure. This corresponds to the effect for an employee randomly drawn from our estimation sample. Our empirical strategy also allows estimating effects for different groups of employees. The average effect on the non-treated (ATENT) is the effect for an employee randomly drawn from the subsample of firms, which did not introduce any health measure. Since firms adopting health measures and their employees differ from those that do not, comparing ATE and ATENT is informative about potential effect heterogeneity. In Appendix B.2, we therefore additionally report the results for the ATENT. They are very similar suggesting that effect heterogeneity is limited. ${ }^{15}$

Table 5.1: Average effects on tenure in the original establishment in days

\begin{tabular}{|c|c|c|c|}
\hline Health promotion measure & Age & Effect & $\mathrm{P}$-value in \% \\
\hline \multirow[t]{3}{*}{ Analysis of sickness absenteeism } & $31-40$ & 83 & 16 \\
\hline & $41-50$ & 48 & 36 \\
\hline & $51-60$ & 54 & 28 \\
\hline \multirow[t]{3}{*}{ Health circles/courses } & $31-40$ & $187^{\star \star}$ & 3 \\
\hline & $41-50$ & $108^{*}$ & 10 \\
\hline & $51-60$ & $147^{\star \star *}$ & 1 \\
\hline
\end{tabular}

\footnotetext{
14 To determine a unique labour market status for each period, the administrative records have been arranged as a panel data set with one observation for each half of a month in the period 1990-2008.

15 The results for the average treatment on the treated (ATET), which is the effect for an employee randomly drawn from the subsample of firms which adopted a specific health measure, are also similar, but less precisely estimated. Detailed results are available on request.
} 
Table 5.1 reports the ATEs on tenure in the firm (from July 2004 onwards) for each of the three age strata. In any of the latter, there are no significant effects of analysing sickness absenteeism, but large positive and statistically significant effects of health circles/courses. After firms introduced these measures, employees stayed with the firm for 4-6 more months longer than if the firm had not introduced these measures. Hence, establishments offering these measures seem to be employers that are more attractive. Moreover, this suggests that firms can save turnover costs by introducing such measures.

Figure 5.1: Average effects on the number of employer changes
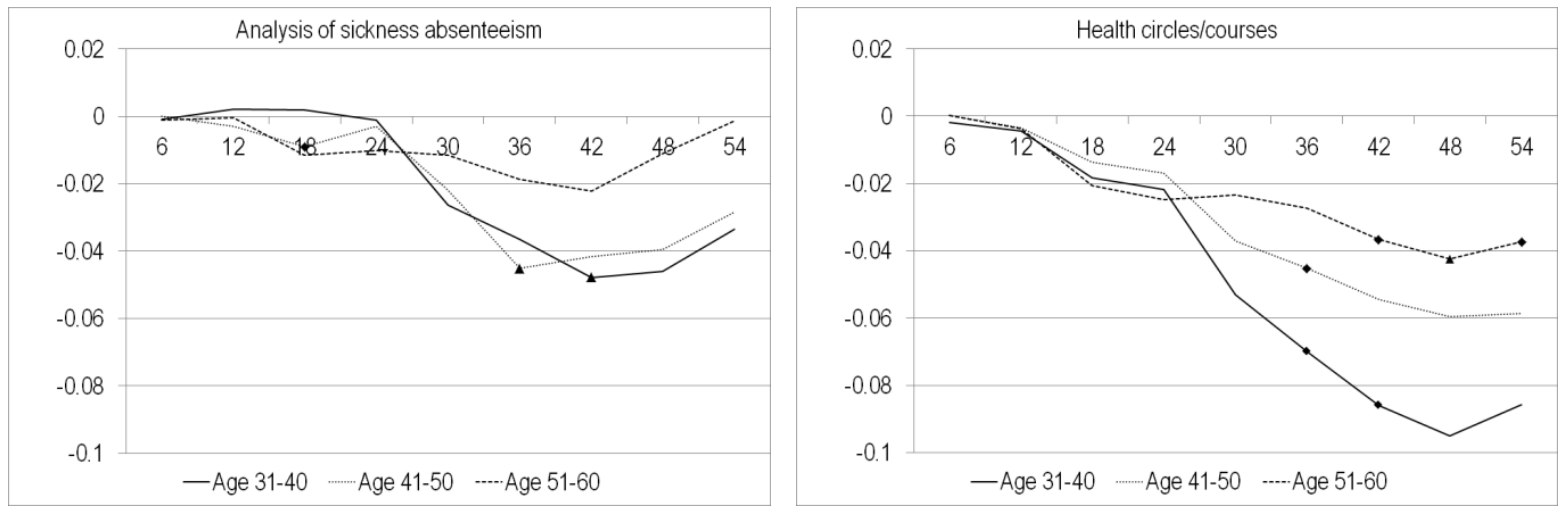

Note: Lines denote average treatment effects on the for respective age stratum. The symbol ' $\boldsymbol{\Lambda}$ ' denotes significance at the $5 \%$ level, while ' denotes significance at the $10 \%$ level. The horizontal axis measures the number of months since June 2004 (half-yearly measurements in June and December of each year). Inference is based on block bootstrapping p-values (clustered at the establishment level, 499 replications).

There is also evidence, though somewhat weaker, that health circles/courses stabilise workers’ careers more generally by reducing the number of employer changes. Figure 5.1 plots half-yearly measurements of the ATEs of introducing the respective health promotion measure compared to not introducing any measure from December 2004 to December 2008. Triangles appear if the effects are significant on the 5\% level and diamond symbols when they are significant on the $10 \%$ level. About 3 years after introduction of the measures we find significant reductions in the number of employer changes of about 4 percentage points for workers aged 51-60, of 5-6 percentage point for 41-50-year olds, and of roughly 8 percentage points for workers aged 31-40. We also estimate drops in the number of employer changes of 
roughly 4-5 percentage points for workers aged 50 or younger about 3 years after first analysing sickness absenteeism. However, few point estimates are significant.

Figures 5.2 to 5.4 plot the ATEs on the cumulated number of months in unsubsidised employment, unemployment or the firm-provided early retirement scheme in a similar fashion as Figure 5.1. Tables B.3 and B.4 in Appendix B.3 report the results for the binary labour market status indicators measured in the second half of June or December of a given year (socalled point-in-time estimates). There are no significant effects of introducing the analysis of sickness absenteeism on any outcome or age group. The only quantitatively larger effects appear for older workers in terms of participation in the firm-provided early retirement scheme, which is reduced by more than one month. The cumulated effects are never significant, while some of the longer run point-in-time estimates are marginally significant (see Table B.3). We do not find any significant or quantitatively noteworthy effects of introducing health circles/courses for workers aged 50 or younger either.

However, there are interesting effects for older workers. After the introduction of health circles/courses, workers aged 51-60 are 4-7 percentage points more likely to be employed than without the introduction of the measures and in total, they spend about 3 months more in unsubsidised employment over the 4.5-year period following June 2004. Moreover, during the first 2 years, the elderly are 3-4 percentage points less likely to be unemployed and receive unemployment insurance payments, and in total they spend about 1.5 months less in unemployment. During the first 1.5 years, they are also roughly 3-4 percentage points less likely to participate in the firm-provided early retirement scheme, which accumulates to being almost one month less in this scheme. ${ }^{16}$ Consequently, tax revenues and social insurance contributions increase while expenditures on unemployment and pension insurance fall.

\footnotetext{
16 The effects on earnings (coded as zero if not employed) show a similar pattern as the effects on employment but are never significant and thus omitted. The results for the other outcomes listed in Table A.1 also support the main conclusions, but lack precision in many cases which is why they are not reported either.
} 
Figure 5.2: Average effects on cumulated unsubsidised employment in months
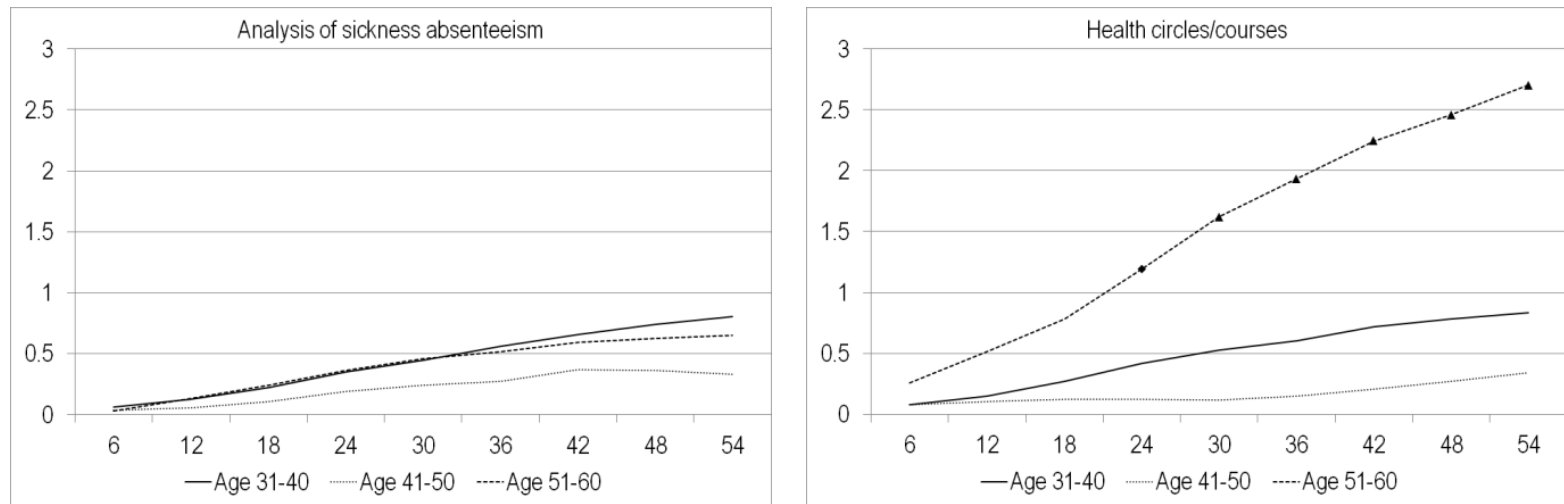

Note: Lines denote average treatment effects on the for respective age stratum. The symbol ' $\mathbf{\Lambda}$ ' denotes significance at the $5 \%$ level, while ' denotes significance at the $10 \%$ level. The horizontal axis measures the number of months since June 2004 (half-yearly measurements in June and December of each year). Inference is based on block bootstrapping p-values (clustered at the establishment level, 499 replications).

Figure 5.3: Average effects on cumulated unemployment in months
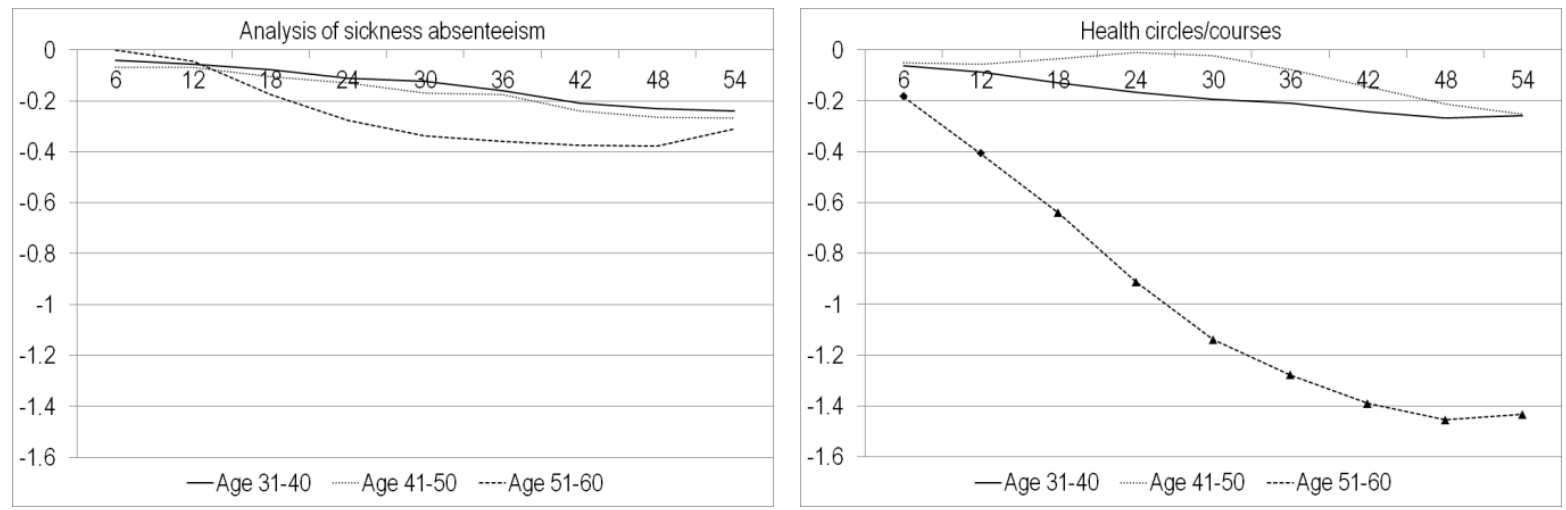

Note: Lines denote average treatment effects on the for respective age stratum. The symbol ' $\mathbf{\Lambda}$ ' denotes significance at the $5 \%$ level, while ' denotes significance at the $10 \%$ level. The horizontal axis measures the number of months since June 2004 (half-yearly measurements in June and December of each year). Inference is based on block bootstrapping p-values (clustered at the establishment level, 499 replications).

The cumulated effects may seem small at first sight. However, because of the tenure requirement we impose for identification purposes, the workers in our sample have a quite strong labour market attachment (they were employed for 85-95\% of the 10 years before July 2002, see Table 3.2). Hence, unemployment risk and incentives to retire early should be comparatively low, which implies that the effects on (the relatively few) workers who would become unemployed or decide to retire early in the absence of the health measures must be quite large. This is confirmed by the relatively large point-in-time effects. It follows that the average effects for older workers with weaker labour market attachment might be even larger. 
However, for the sake of minimising self-selection into firms, we here focus on a more narrowly defined population of workers.

Figure 5.4: Average effects on months in firm-provided early retirement schemes
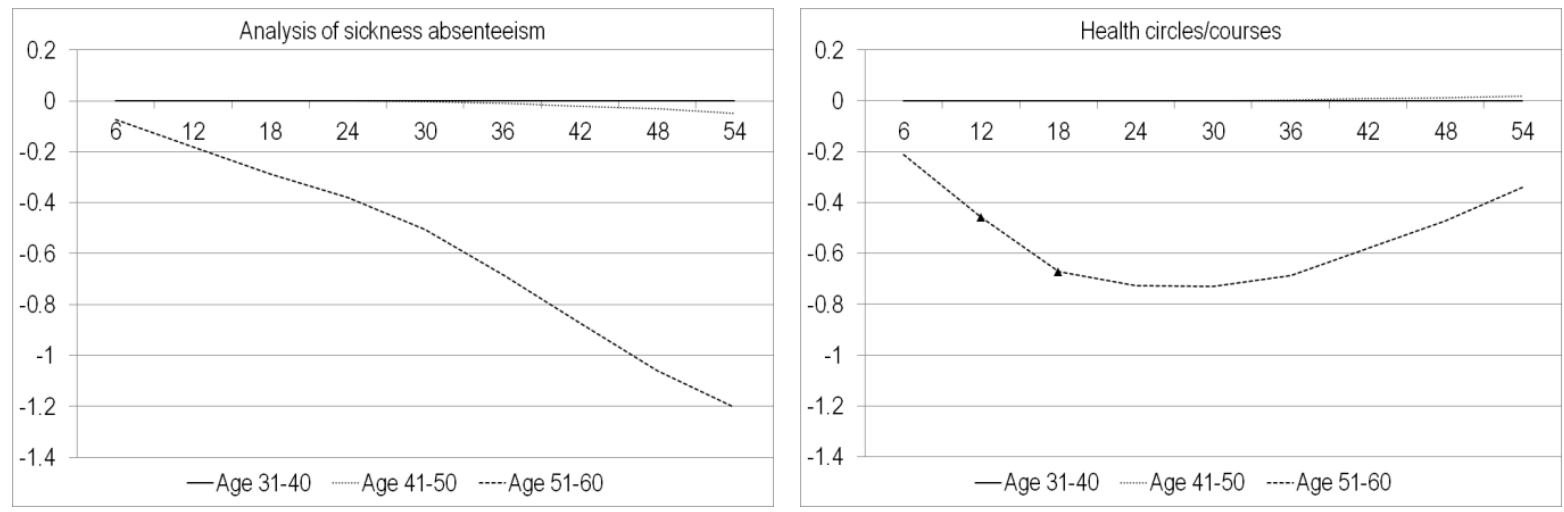

Note: Lines denote average treatment effects on the for respective age stratum. The symbol ' $\mathbf{\Delta}$ ' denotes significance at the $5 \%$ level, while ' denotes significance at the $10 \%$ level. The horizontal axis measures the number of months since June 2004 (half-yearly measurements in June and December of each year). Inference is based on block bootstrapping p-values (clustered at the establishment level, 499 replications).

The results also provide some insights on the credibility of our identification strategy. Firstly, if controlling for the variables available in the data was not sufficient for removing selection bias, one might see immediate 'effects' in the figures presented above, as there is no obvious reason why selection effects would need time to materialize - as opposed to true effects. However, effects immediately after introducing the health measures are largely absent and never significant, thus providing no evidence against the validity of our selection-on-observables strategy. Secondly, the fact that we mainly find effects for older workers, who are most likely to suffer from health problems, but not for younger workers in the same firms also speaks against selection effects, which should be similar for all employees of a firm. Finally, the firms which introduced health circles/courses are operating in less favourable labour markets than those which do not (see Table 3.2), suggesting that selection effects should lead to worse labour market outcomes of their employees. The fact that we find opposite effects supports our identification strategy. 


\section{Conclusions}

In this paper, we complement the literature on the effects of firm-provided workplace health promotion measures on workers' health and firms' economic situation by studying the effects on future labour market outcomes of the firms' employees. Identification exploits rich survey and administrative data and is based on a combination of a selection-on-observables assumption and a particular usage of the panel structure of the data that allows controlling for time-constant unobserved factors and differential time trends. For estimation, we apply semiparametric radius matching on the propensity score with regression adjustment, which is flexible in terms of functional form assumptions and permits arbitrary effect heterogeneity with respect to observables.

Our results suggest that analyses of sickness absenteeism, which involve employees only passively, have a rather limited impact on individual labour market outcomes by slightly reducing the number of job changes for younger workers. In contrast, health circles and health courses, which require an active engagement of the employees, appear to have a more profound impact. They decrease the number of job changes in general (and more profoundly than the analyses of sickness absenteeism) leading to more stable work careers. Moreover, they increase tenure with the studied firm by 4-6 months for all age groups, which implies savings for firms in terms of turnover costs that come in addition to health-related cost savings documented in the existing literature. Finally and maybe most important from a policy perspective, health circles and health courses also increase the labour market attachment of older workers. They increase employment and reduce unemployment of these workers. They also reduce participation in special firm-provided early retirement schemes. Therefore, tax revenues and social insurance contributions increase while expenditures on unemployment and pension insurance fall. Again, this comes on top of the positive effects on workers' health and the corresponding health-related cost savings documented in the earlier literature. Thus, it 
might be advisable for policy makers to encourage firms to introduce health circles or health courses, especially given the demographic development in many countries.

Further research should be devoted to a more thorough investigation of heterogeneity patterns to permit a more precise targeting of health promotion activities to groups that benefit most. Possible dimensions of interest are specific industries and occupations as well as particular types of employees with specific health risks, none of which could be investigated in this study due to sample size issues.

\section{Literature}

Abadie, A., and G. W. Imbens (2006): "Large Sample Properties of Matching Estimators for Average Treatment Effects", Econometrica, 74, 235-267.

Abadie, A., and G. W. Imbens (2008): "On the Failure of the Bootstrap for Matching Estimators", Econometrica, 76, 1537-1557.

Biewen, M., B. Fitzenberger, R. Osikominu, and M. Paul (2013): “The Effectiveness of Public Sponsored Training Revisited: The Importance of Data and Methodological Choices”, forthcoming in Journal of Labor Economics.

BMAS (2014): "Sicherheit und Gesundheit bei der Arbeit 2012 - Unfallverhütungsbericht Arbeit“, Bundesministerium für Arbeit und Soziales (BMAS).

Böckerman P., and P. Ilmakunnas (2009): "Unemployment And Self-Assessed Health: Evidence From Panel Data", Health Economics, 18, 161-179.

Dehejia, R. H., and S. Wahba (2002): "Propensity-Score-Matching Methods for Nonexperimental Causal Studies", Review of Economics and Statistics, 84, 151-161.

Fielding, J. E., and P. V. Piserchia (1989): "Frequency of worksite health promotion activities", American Journal of Public Health, 79, 16-20.

Hollederer, A. (2007): "Betriebliche Gesundheitsförderung in Deutschland-Ergebnisse des IAB-Betriebspanels 2002 und 2004", Gesundheitswesen, 69, 63-76.

Huber, M., M. Lechner, and C. Wunsch (2011): "Does Leaving Welfare Improve Health? Evidence for Germany", Health Economics, 20, 484-504.

Huber, M., M. Lechner, and C. Wunsch (2013): "The Performance of Estimators Based on the Propensity Score“, Journal of Econometrics, 175, 1-21.

IGA (2009): "Health in the workplace - A guide to health at work", published by Initiative Gesundheit und Arbeit (IGA), BKK Bundesverband, Deutsche Gesetzliche Unfallversicherung, BGAG - Institut Arbeit und Gesundheit der DGUV, AOK-Bundesverband, Verband der Ersatzkassen e.V.. 
Joffe, M. M., T. R. Have, H. I. Feldman, and S. Kimmel (2004): "Model Selection, Confounder Control, and Marginal Structural Models", The American Statistician, 58-4, 272-279.

Jung, J., A. Nitzsche, L. Ansmann, N. Ernstmann, O. Ommen, B. Stieler-Lorenz, J. Wasem, and H. Pfaff (2012): "Organizational factors and the attitude toward health promotion in German ICT-companies", Health Promotion International, 27, 382-393.

Kenkel, D., and D. Supina (1992): The determinants of worksite health promotion, Economics Letters, 40, 345351.

Kreis, J. and W. Bödeker (2004): "Health-related and economic benefits of workplace health promotion and prevention - Summary of the scientific evidence”, IGA Report 3e, published by the BKK Federation and the Federation of Institutions for Statutory Accident Insurance and Prevention.

Lechner, M. (2002): Some practical issues in the evaluation of heterogeneous labour market programmes by matching methods, Journal of the Royal Statistical Society, Series A, Statistics in Society, 165, 59-82.

Lechner, M. and C. Wunsch (2013): "Sensitivity of Matching-Based Program Evaluations to the Availability of Control Variables", Labour Economics, 21, 111-121.

Lechner, M., R. Miquel, and C. Wunsch (2011): "Long-Run Effects of Public Sector Sponsored Training in West Germany", Journal of the European Economic Association, 9, 742-784.

MacKinnon, J. G. (2006). "Bootstrap Methods in Econometrics", The Economic Record, 82, 2-18.

New York Times (2013): “As OSHA Emphasizes Safety, Long-Term Health Risks Fester”, online edition, http://www.nytimes.com/2013/03/31/us/osha-emphasizes-safety-health-risks-fester.html (accessed August, 26, 2013).

Köhler, T., C. Janssen, C. S. Plath, S. Steinhausen, and H. Pfaff (2009): "Determinanten der betrieblichen Gesundheitsförderung in der Versicherungsbranche: Ergebnisse einer Vollerhebung bei deutschen Versicherungen im Jahr 2006", Gesundheitswesen, 71, 722-731.

Rosenbaum, P. R., and D. B. Rubin (1983): "The central role of the propensity score in observational studies for causal effects", Biometrika, 70, 41-50.

Rubin, D. B. (1979): "Using Multivariate Matched Sampling and Regression Adjustment to Control Bias in Observational Studies", Journal of the American Statistical Association, 74, 318-328.

Sockoll, I., I. Kramer, and W. Bödeker (2009): “Effectiveness and economic benefits of workplace health promotion and prevention - Summary of the scientific evidence 2000 to 2006”, IGA Report 13e, published by the Federal Association of Company Health Insurance Funds.

Ulmer, J. and F. Gröben (2005): "Work place health promotion. A longitudinal study in companies placed in Hessen and Thueringen", Journal of Public Health, 13, 144-152.

Wunsch, C. (2013): “Optimal Use of Labor Market Policies: The Role of Job Search Assistance“, Review of Economics and Statistics, 95, 1030-1045.

Wunsch, C., and M. Lechner (2008): "What Did All the Money Do? On the General Ineffectiveness of Recent West German Labour Market Programmes", Kyklos, 61, 134-174. 


\section{Appendix A: Further descriptive statistics}

Table A.1: Transition matrix for the use of different health measures

(a) Analysis of sickness absenteeism

\begin{tabular}{cccc}
\hline \hline & & 2004 & \\
2002 & No & Yes & Total \\
\hline No & 460 & 308 & 768 \\
Yes & 340 & 1,123 & 1,463 \\
Total & 800 & 1,431 & 2,231 \\
\hline
\end{tabular}

(b) Surveys of employees about health risks at the workplace

\begin{tabular}{cccc}
\hline \hline & & & \\
2002 & No & 2004 & Total \\
\hline No & 1,102 & 344 & 1,446 \\
Yes & 354 & 431 & 785 \\
Total & 1,456 & 775 & 2,231 \\
\hline
\end{tabular}

(c) Discussion groups about health problems in the workplace (health circles)

\begin{tabular}{cccc}
\hline \hline & & & \\
2002 & No & 2004 & Yes \\
\hline No & 1,456 & 218 & Total \\
Yes & 276 & 281 & 557 \\
Total & 1,732 & 499 & 2,231 \\
\hline
\end{tabular}

(d) Courses with information about healthy behaviour

\begin{tabular}{cccc}
\hline \hline & & & \\
2002 & No & 2004 & Total \\
\hline No & 1,230 & 322 & 1,552 \\
Yes & 253 & 426 & 679 \\
Total & 1,483 & 748 & 2,231 \\
\hline
\end{tabular}

Note: The numbers refer to all establishments, which participated in the 2002 and in the 2004 waves of the IAB Establishment Panel, have non-missing entries for the respective question and are part of the linked-employer-employee data used in this project. The shaded cells indicate the firms that are relevant for the empirical analysis before removing firms with at least one measure in 2002 and before applying further restrictions to ensure common support. 
Table A.2: Outcome variables

\begin{tabular}{|c|c|c|c|c|c|c|c|c|c|c|}
\hline \multicolumn{2}{|c|}{ Age of worker in 2004} & \multicolumn{3}{|c|}{31 to 40} & \multicolumn{3}{|c|}{41 to 50} & \multicolumn{3}{|c|}{51 to 60} \\
\hline \multicolumn{2}{|c|}{ Establishment health policy (treatment) } & None & SickA & Cour & None & SickA & Cour & None & SickA & Cour \\
\hline \multirow[t]{9}{*}{ Employed end of } & $2 / 2004$ & 0.92 & 0.93 & 0.94 & 0.92 & 0.93 & 0.95 & 0.81 & 0.82 & 0.84 \\
\hline & $1 / 2005$ & 0.91 & 0.92 & 0.92 & 0.91 & 0.93 & 0.93 & 0.76 & 0.78 & 0.79 \\
\hline & $2 / 2005$ & 0.90 & 0.91 & 0.92 & 0.90 & 0.92 & 0.93 & 0.72 & 0.74 & 0.76 \\
\hline & $1 / 2006$ & 0.90 & 0.92 & 0.92 & 0.90 & 0.91 & 0.92 & 0.69 & 0.70 & 0.73 \\
\hline & $2 / 2006$ & 0.90 & 0.92 & 0.92 & 0.90 & 0.91 & 0.92 & 0.66 & 0.67 & 0.70 \\
\hline & $1 / 2007$ & 0.90 & 0.92 & 0.91 & 0.89 & 0.90 & 0.91 & 0.62 & 0.64 & 0.66 \\
\hline & $2 / 2007$ & 0.90 & 0.90 & 0.91 & 0.88 & 0.89 & 0.91 & 0.60 & 0.60 & 0.63 \\
\hline & $1 / 2008$ & 0.89 & 0.90 & 0.90 & 0.88 & 0.88 & 0.91 & 0.56 & 0.57 & 0.59 \\
\hline & $2 / 2008$ & 0.89 & 0.90 & 0.90 & 0.87 & 0.87 & 0.90 & 0.54 & 0.54 & 0.57 \\
\hline \multirow[t]{9}{*}{ Minor employment end of } & $2 / 2004$ & 0.04 & 0.04 & 0.04 & 0.03 & 0.04 & 0.03 & 0.04 & 0.04 & 0.05 \\
\hline & $1 / 2005$ & 0.04 & 0.05 & 0.05 & 0.04 & 0.04 & 0.03 & 0.05 & 0.04 & 0.04 \\
\hline & $2 / 2005$ & 0.04 & 0.05 & 0.04 & 0.04 & 0.04 & 0.03 & 0.05 & 0.04 & 0.04 \\
\hline & $1 / 2006$ & 0.05 & 0.05 & 0.05 & 0.04 & 0.04 & 0.04 & 0.05 & 0.05 & 0.05 \\
\hline & $2 / 2006$ & 0.05 & 0.05 & 0.05 & 0.04 & 0.04 & 0.04 & 0.05 & 0.05 & 0.05 \\
\hline & $1 / 2007$ & 0.05 & 0.05 & 0.05 & 0.04 & 0.04 & 0.03 & 0.06 & 0.05 & 0.06 \\
\hline & $2 / 2007$ & 0.04 & 0.05 & 0.05 & 0.04 & 0.04 & 0.03 & 0.06 & 0.06 & 0.06 \\
\hline & $1 / 2008$ & 0.05 & 0.05 & 0.05 & 0.04 & 0.04 & 0.04 & 0.06 & 0.07 & 0.05 \\
\hline & $2 / 2008$ & 0.05 & 0.05 & 0.05 & 0.04 & 0.04 & 0.04 & 0.07 & 0.07 & 0.06 \\
\hline \multirow{9}{*}{$\begin{array}{l}\text { In early retirement } \\
\text { scheme end of }\end{array}$} & $2 / 2004$ & 0.00 & 0.00 & 0.00 & 0.00 & 0.00 & 0.00 & 0.12 & 0.11 & 0.10 \\
\hline & $1 / 2005$ & 0.00 & 0.00 & 0.00 & 0.00 & 0.00 & 0.00 & 0.12 & 0.11 & 0.11 \\
\hline & $2 / 2005$ & 0.00 & 0.00 & 0.00 & 0.00 & 0.00 & 0.00 & 0.12 & 0.11 & 0.11 \\
\hline & $1 / 2006$ & 0.00 & 0.00 & 0.00 & 0.00 & 0.00 & 0.00 & 0.12 & 0.11 & 0.13 \\
\hline & $2 / 2006$ & 0.00 & 0.00 & 0.00 & 0.00 & 0.00 & 0.00 & 0.12 & 0.10 & 0.14 \\
\hline & $1 / 2007$ & 0.00 & 0.00 & 0.00 & 0.00 & 0.00 & 0.00 & 0.12 & 0.10 & 0.15 \\
\hline & $2 / 2007$ & 0.00 & 0.00 & 0.00 & 0.00 & 0.00 & 0.01 & 0.11 & 0.09 & 0.15 \\
\hline & $1 / 2008$ & 0.00 & 0.00 & 0.00 & 0.00 & 0.00 & 0.01 & 0.11 & 0.09 & 0.15 \\
\hline & $2 / 2008$ & 0.00 & 0.00 & 0.00 & 0.01 & 0.00 & 0.01 & 0.11 & 0.09 & 0.15 \\
\hline \multirow[t]{9}{*}{ Unemployed end of } & $2 / 2004$ & 0.04 & 0.03 & 0.02 & 0.04 & 0.03 & 0.02 & 0.07 & 0.07 & 0.04 \\
\hline & $1 / 2005$ & 0.04 & 0.04 & 0.03 & 0.04 & 0.04 & 0.03 & 0.08 & 0.07 & 0.05 \\
\hline & $2 / 2005$ & 0.04 & 0.04 & 0.03 & 0.05 & 0.04 & 0.03 & 0.10 & 0.07 & 0.05 \\
\hline & $1 / 2006$ & 0.04 & 0.04 & 0.03 & 0.05 & 0.04 & 0.03 & 0.10 & 0.09 & 0.05 \\
\hline & $2 / 2006$ & 0.03 & 0.03 & 0.02 & 0.04 & 0.04 & 0.03 & 0.09 & 0.08 & 0.05 \\
\hline & $1 / 2007$ & 0.03 & 0.03 & 0.02 & 0.04 & 0.04 & 0.03 & 0.08 & 0.07 & 0.05 \\
\hline & $2 / 2007$ & 0.03 & 0.03 & 0.02 & 0.04 & 0.03 & 0.02 & 0.07 & 0.06 & 0.04 \\
\hline & $1 / 2008$ & 0.03 & 0.03 & 0.02 & 0.04 & 0.03 & 0.02 & 0.06 & 0.05 & 0.04 \\
\hline & $2 / 2008$ & 0.03 & 0.03 & 0.02 & 0.04 & 0.04 & 0.02 & 0.04 & 0.04 & 0.03 \\
\hline \multirow{9}{*}{$\begin{array}{l}\text { Received unemployment } \\
\text { benefits end of }\end{array}$} & $2 / 2004$ & 0.02 & 0.02 & 0.01 & 0.03 & 0.02 & 0.02 & 0.07 & 0.06 & 0.04 \\
\hline & $1 / 2005$ & 0.02 & 0.02 & 0.01 & 0.03 & 0.02 & 0.03 & 0.07 & 0.06 & 0.04 \\
\hline & $2 / 2005$ & 0.02 & 0.02 & 0.01 & 0.03 & 0.02 & 0.02 & 0.09 & 0.06 & 0.04 \\
\hline & $1 / 2006$ & 0.02 & 0.01 & 0.01 & 0.03 & 0.02 & 0.02 & 0.08 & 0.08 & 0.04 \\
\hline & 2/2006 & 0.01 & 0.01 & 0.01 & 0.02 & 0.02 & 0.02 & 0.07 & 0.07 & 0.04 \\
\hline & $1 / 2007$ & 0.01 & 0.01 & 0.01 & 0.03 & 0.02 & 0.01 & 0.07 & 0.06 & 0.04 \\
\hline & 2/2007 & 0.02 & 0.01 & 0.01 & 0.02 & 0.01 & 0.01 & 0.06 & 0.05 & 0.03 \\
\hline & $1 / 2008$ & 0.02 & 0.01 & 0.01 & 0.02 & 0.01 & 0.01 & 0.04 & 0.04 & 0.03 \\
\hline & 2/2008 & 0.01 & 0.02 & 0.01 & 0.02 & 0.02 & 0.01 & 0.03 & 0.03 & 0.02 \\
\hline \multirow[t]{9}{*}{ Out-of-labour-force end of } & $2 / 2004$ & 0.04 & 0.03 & 0.04 & 0.03 & 0.03 & 0.03 & 0.12 & 0.11 & 0.12 \\
\hline & $1 / 2005$ & 0.05 & 0.04 & 0.05 & 0.04 & 0.03 & 0.03 & 0.16 & 0.14 & 0.15 \\
\hline & $2 / 2005$ & 0.05 & 0.05 & 0.06 & 0.04 & 0.04 & 0.03 & 0.18 & 0.18 & 0.19 \\
\hline & $1 / 2006$ & 0.06 & 0.04 & 0.06 & 0.05 & 0.04 & 0.04 & 0.21 & 0.21 & 0.21 \\
\hline & 2/2006 & 0.06 & 0.05 & 0.06 & 0.05 & 0.05 & 0.04 & 0.24 & 0.24 & 0.24 \\
\hline & $1 / 2007$ & 0.06 & 0.05 & 0.07 & 0.06 & 0.05 & 0.06 & 0.29 & 0.28 & 0.29 \\
\hline & 2/2007 & 0.07 & 0.06 & 0.07 & 0.07 & 0.07 & 0.06 & 0.32 & 0.32 & 0.32 \\
\hline & $1 / 2008$ & 0.07 & 0.06 & 0.07 & 0.07 & 0.08 & 0.07 & 0.37 & 0.37 & 0.36 \\
\hline & 2/2008 & 0.08 & 0.07 & 0.07 & 0.08 & 0.09 & 0.07 & 0.41 & 0.40 & 0.39 \\
\hline
\end{tabular}

Note: Table A.2 to be continued. 


\begin{tabular}{|c|c|c|c|c|c|c|c|c|c|c|}
\hline \multicolumn{2}{|c|}{ Age of worker in 2004} & \multicolumn{3}{|c|}{31 to 40} & \multicolumn{3}{|c|}{41 to 50} & \multicolumn{3}{|c|}{51 to 60} \\
\hline \multicolumn{2}{|c|}{ Establishment health policy (treatment) } & None & SickA & Cour & None & SickA & Cour & None & SickA & Cour \\
\hline \multirow{9}{*}{$\begin{array}{l}\text { Cumulated half months of } \\
\text { employment until end of }\end{array}$} & $2 / 2004$ & 11.07 & 11.17 & 11.30 & 11.16 & 11.28 & 11.48 & 9.89 & 9.97 & 10.22 \\
\hline & $1 / 2005$ & 21.97 & 22.16 & 22.34 & 22.16 & 22.42 & 22.70 & 19.21 & 19.48 & 19.84 \\
\hline & $2 / 2005$ & 32.78 & 33.13 & 33.38 & 33.06 & 33.49 & 33.90 & 28.07 & 28.57 & 29.12 \\
\hline & $1 / 2006$ & 43.53 & 44.09 & 44.40 & 43.85 & 44.48 & 45.01 & 36.39 & 37.11 & 38.05 \\
\hline & $2 / 2006$ & 54.36 & 55.09 & 55.39 & 54.68 & 55.41 & 56.08 & 44.43 & 45.32 & 46.66 \\
\hline & $1 / 2007$ & 65.16 & 66.07 & 66.33 & 65.44 & 66.25 & 67.06 & 52.08 & 53.14 & 54.74 \\
\hline & $2 / 2007$ & 75.94 & 76.99 & 77.24 & 76.09 & 77.05 & 78.03 & 59.35 & 60.55 & 62.46 \\
\hline & $1 / 2008$ & 86.65 & 87.82 & 88.11 & 86.69 & 87.67 & 88.94 & 66.22 & 67.50 & 69.64 \\
\hline & $2 / 2008$ & 97.36 & 98.64 & 98.99 & 97.25 & 98.17 & 99.78 & 72.79 & 74.15 & 76.55 \\
\hline \multirow{9}{*}{$\begin{array}{l}\text { Cumulated half-months in } \\
\text { minor emploment until } \\
\text { end of }\end{array}$} & $2 / 2004$ & 0.45 & 0.50 & 0.47 & 0.39 & 0.46 & 0.37 & 0.48 & 0.47 & 0.55 \\
\hline & $1 / 2005$ & 0.98 & 1.12 & 1.03 & 0.84 & 0.95 & 0.76 & 1.02 & 0.95 & 1.05 \\
\hline & 2/2005 & 1.50 & 1.72 & 1.57 & 1.28 & 1.40 & 1.15 & 1.57 & 1.43 & 1.56 \\
\hline & $1 / 2006$ & 2.06 & 2.32 & 2.13 & 1.76 & 1.95 & 1.62 & 2.14 & 1.97 & 2.14 \\
\hline & $2 / 2006$ & 2.62 & 2.93 & 2.70 & 2.24 & 2.45 & 2.10 & 2.78 & 2.55 & 2.78 \\
\hline & $1 / 2007$ & 3.21 & 3.61 & 3.35 & 2.74 & 2.98 & 2.52 & 3.42 & 3.17 & 3.43 \\
\hline & $2 / 2007$ & 3.75 & 4.21 & 3.94 & 3.23 & 3.50 & 2.93 & 4.12 & 3.87 & 4.10 \\
\hline & $1 / 2008$ & 4.32 & 4.80 & 4.51 & 3.74 & 4.04 & 3.44 & 4.85 & 4.62 & 4.76 \\
\hline & 2/2008 & 4.87 & 5.41 & 5.08 & 4.25 & 4.55 & 3.92 & 5.66 & 5.43 & 5.45 \\
\hline \multirow{9}{*}{$\begin{array}{l}\text { Cumulated half-months in } \\
\text { early retirement scheme } \\
\text { until end of }\end{array}$} & $2 / 2004$ & 0.00 & 0.00 & 0.00 & 0.00 & 0.00 & 0.00 & 1.41 & 1.31 & 1.28 \\
\hline & $1 / 2005$ & 0.00 & 0.00 & 0.00 & 0.00 & 0.00 & 0.00 & 2.80 & 2.58 & 2.51 \\
\hline & $2 / 2005$ & 0.00 & 0.00 & 0.00 & 0.00 & 0.00 & 0.00 & 4.21 & 3.86 & 3.82 \\
\hline & $1 / 2006$ & 0.00 & 0.00 & 0.00 & 0.00 & 0.00 & 0.00 & 5.63 & 5.16 & 5.33 \\
\hline & $2 / 2006$ & 0.00 & 0.00 & 0.00 & 0.01 & 0.00 & 0.01 & 7.07 & 6.45 & 7.01 \\
\hline & $1 / 2007$ & 0.00 & 0.00 & 0.00 & 0.03 & 0.01 & 0.04 & 8.52 & 7.65 & 8.76 \\
\hline & $2 / 2007$ & 0.00 & 0.00 & 0.00 & 0.07 & 0.03 & 0.10 & 9.93 & 8.81 & 10.59 \\
\hline & $1 / 2008$ & 0.00 & 0.00 & 0.00 & 0.13 & 0.06 & 0.17 & 11.29 & 9.92 & 12.37 \\
\hline & $2 / 2008$ & 0.00 & 0.00 & 0.00 & 0.21 & 0.10 & 0.28 & 12.61 & 11.03 & 14.14 \\
\hline \multirow{9}{*}{$\begin{array}{l}\text { Cumulated half months in } \\
\text { unemployment until } \\
\text { end of }\end{array}$} & $2 / 2004$ & 0.43 & 0.41 & 0.26 & 0.49 & 0.38 & 0.27 & 0.79 & 0.75 & 0.43 \\
\hline & $1 / 2005$ & 0.87 & 0.89 & 0.57 & 0.99 & 0.85 & 0.64 & 1.70 & 1.59 & 0.99 \\
\hline & $2 / 2005$ & 1.36 & 1.36 & 0.88 & 1.56 & 1.33 & 1.03 & 2.76 & 2.42 & 1.57 \\
\hline & $1 / 2006$ & 1.84 & 1.82 & 1.19 & 2.15 & 1.81 & 1.42 & 4 & 3.43 & 2.20 \\
\hline & $2 / 2006$ & 2.25 & 2.21 & 1.47 & 2.69 & 2.27 & 1.77 & 5.09 & 4.41 & 2.76 \\
\hline & $1 / 2007$ & 2.63 & 2.57 & 1.73 & 3.18 & 2.73 & 2.08 & 6.10 & 5.27 & 3.35 \\
\hline & $2 / 2007$ & 3.00 & 2.91 & 1.94 & 3.69 & 3.15 & 2.36 & 7.02 & 6.07 & 3.88 \\
\hline & $1 / 2008$ & 3.36 & 3.30 & 2.17 & 4.16 & 3.55 & 2.65 & 7.84 & 6.75 & 4.41 \\
\hline & $2 / 2008$ & 3.68 & 3.66 & 2.39 & 4.60 & 3.95 & 2.93 & 8.37 & 7.31 & 4.84 \\
\hline \multirow{9}{*}{$\begin{array}{l}\text { Cumulated half months in } \\
\text { income support ('Hartz IV') } \\
\text { end middle of }\end{array}$} & $2 / 2004$ & 0.00 & 0.00 & 0.00 & 0.00 & 0.00 & 0.00 & 0.00 & 0.00 & 0.00 \\
\hline & $1 / 2005$ & 0.15 & 0.20 & 0.12 & 0.10 & 0.13 & 0.09 & 0.06 & 0.09 & 0.08 \\
\hline & 2/2005 & 0.30 & 0.40 & 0.22 & 0.19 & 0.26 & 0.20 & 0.13 & 0.17 & 0.14 \\
\hline & $1 / 2006$ & 0.46 & 0.61 & 0.33 & 0.30 & 0.41 & 0.31 & 0.22 & 0.25 & 0.20 \\
\hline & $2 / 2006$ & 0.62 & 0.83 & 0.45 & 0.41 & 0.56 & 0.43 & 0.32 & 0.35 & 0.28 \\
\hline & $1 / 2007$ & 0.77 & 1.04 & 0.58 & 0.52 & 0.73 & 0.57 & 0.44 & 0.46 & 0.37 \\
\hline & $2 / 2007$ & 0.93 & 1.24 & 0.70 & 0.62 & 0.89 & 0.71 & 0.55 & 0.59 & 0.47 \\
\hline & $1 / 2008$ & 1.08 & 1.45 & 0.81 & 0.72 & 1.07 & 0.85 & 0.68 & 0.74 & 0.58 \\
\hline & $2 / 2008$ & 1.22 & 1.65 & 0.93 & 0.83 & 1.24 & 0.96 & 0.80 & 0.87 & 0.69 \\
\hline \multirow{9}{*}{$\begin{array}{l}\text { Part-time employed } \\
\text { end of }\end{array}$} & $2 / 2004$ & 0.17 & 0.16 & 0.25 & 0.19 & 0.19 & 0.28 & 0.25 & 0.21 & 0.29 \\
\hline & $1 / 2005$ & 0.18 & 0.16 & 0.25 & 0.19 & 0.19 & 0.29 & 0.24 & 0.22 & 0.28 \\
\hline & $2 / 2005$ & 0.18 & 0.16 & 0.25 & 0.19 & 0.19 & 0.29 & 0.24 & 0.21 & 0.28 \\
\hline & $1 / 2006$ & 0.19 & 0.17 & 0.25 & 0.20 & 0.20 & 0.29 & 0.24 & 0.21 & 0.28 \\
\hline & $2 / 2006$ & 0.19 & 0.17 & 0.26 & 0.20 & 0.19 & 0.29 & 0.23 & 0.21 & 0.28 \\
\hline & $1 / 2007$ & 0.19 & 0.17 & 0.26 & 0.20 & 0.20 & 0.29 & 0.22 & 0.20 & 0.28 \\
\hline & $2 / 2007$ & 0.19 & 0.17 & 0.26 & 0.20 & 0.19 & 0.29 & 0.22 & 0.19 & 0.27 \\
\hline & $1 / 2008$ & 0.19 & 0.17 & 0.26 & 0.20 & 0.19 & 0.29 & 0.21 & 0.19 & 0.25 \\
\hline & $2 / 2008$ & 0.19 & 0.17 & 0.26 & 0.20 & 0.19 & 0.29 & 0.21 & 0.19 & 0.25 \\
\hline \multicolumn{2}{|c|}{ Tenure after June 30,2004 in days } & 1777 & 1897 & 1899 & 1872 & 1973 & 2001 & 1540 & 1630 & 1667 \\
\hline
\end{tabular}

Note: Table A.2 to be continued. 


\begin{tabular}{|c|c|c|c|c|c|c|c|c|c|c|}
\hline \multicolumn{2}{|c|}{ Age of worker in 2004} & \multicolumn{3}{|c|}{31 to 40} & \multicolumn{3}{|c|}{41 to 50} & \multicolumn{3}{|c|}{51 to 60} \\
\hline \multicolumn{2}{|c|}{ Establishment health policy (treatment) } & None & SickA & Cour & None & SickA & Cour & None & SickA & Cour \\
\hline \multirow{9}{*}{$\begin{array}{l}\text { Half monthly earnings } \\
\text { end of }\end{array}$} & $2 / 2004$ & 1184 & 1196 & 1179 & 1226 & 1232 & 1234 & 1062 & 1098 & 1039 \\
\hline & $1 / 2005$ & 1157 & 1175 & 1164 & 1197 & 1208 & 1194 & 982 & 1031 & 969 \\
\hline & $2 / 2005$ & 1152 & 1173 & 1164 & 1188 & 1205 & 1193 & 932 & 990 & 939 \\
\hline & $1 / 2006$ & 1150 & 1175 & 1152 & 1173 & 1188 & 1159 & 870 & 920 & 873 \\
\hline & $2 / 2006$ & 1144 & 1179 & 1153 & 1169 & 1183 & 1157 & 834 & 888 & 839 \\
\hline & $1 / 2007$ & 1139 & 1172 & 1129 & 1143 & 1167 & 1130 & 769 & 822 & 766 \\
\hline & $2 / 2007$ & 1138 & 1167 & 1133 & 1142 & 1159 & 1137 & 734 & 773 & 732 \\
\hline & $1 / 2008$ & 1127 & 1148 & 1131 & 1124 & 1115 & 1113 & 671 & 709 & 671 \\
\hline & $2 / 2008$ & 1128 & 1151 & 1132 & 1116 & 1114 & 1107 & 642 & 671 & 648 \\
\hline \multirow{9}{*}{$\begin{array}{l}\text { Cumulated half-months in } \\
\text { Part-time employment until } \\
\text { end of }\end{array}$} & $2 / 2004$ & 2.09 & 1.88 & 2.96 & 2.30 & 2.25 & 3.42 & 3.05 & 2.61 & 3.60 \\
\hline & $1 / 2005$ & 4.22 & 3.84 & 6 & 4.64 & 4.56 & 6.92 & 6.01 & 5.25 & 7.01 \\
\hline & 2/2005 & 6.35 & 5.78 & 9.03 & 6.96 & 6.84 & 10.40 & 8.88 & 7.79 & 10.39 \\
\hline & $1 / 2006$ & 8.56 & 7.79 & 12.05 & 9.32 & 9.24 & 13.95 & 11.71 & 10.33 & 13.76 \\
\hline & $2 / 2006$ & 10.82 & 9.82 & 15.12 & 11.68 & 11.59 & 17.48 & 14.52 & 12.85 & 17.15 \\
\hline & $1 / 2007$ & 13.06 & 11.92 & 18.25 & 14.05 & 13.96 & 21 & 17.26 & 15.31 & 20.53 \\
\hline & $2 / 2007$ & 15.34 & 13.96 & 21.38 & 16.48 & 16.32 & 24.49 & 19.92 & 17.68 & 23.84 \\
\hline & $1 / 2008$ & 17.65 & 15.98 & 24.46 & 18.90 & 18.66 & 28.04 & 22.48 & 19.99 & 26.96 \\
\hline & 2/2008 & 19.97 & 18.02 & 27.55 & 21.35 & 20.99 & 31.54 & 25.01 & 22.26 & 29.97 \\
\hline \multirow{9}{*}{$\begin{array}{l}\text { Cumulated earnings /100 } \\
\text { until end of }\end{array}$} & $2 / 2004$ & 142 & 144 & 141 & 147 & 148 & 148 & 129 & 133 & 126 \\
\hline & $1 / 2005$ & 281 & 285 & 280 & 291 & 293 & 291 & 249 & 259 & 243 \\
\hline & $2 / 2005$ & 420 & 426 & 420 & 434 & 438 & 434 & 363 & 380 & 358 \\
\hline & $1 / 2006$ & 557 & 567 & 558 & 575 & 580 & 573 & 469 & 493 & 464 \\
\hline & $2 / 2006$ & 695 & 708 & 696 & 715 & 723 & 712 & 571 & 602 & 566 \\
\hline & $1 / 2007$ & 831 & 848 & 832 & 852 & 863 & 848 & 665 & 702 & 660 \\
\hline & $2 / 2007$ & 968 & 989 & 968 & 989 & 1003 & 984 & 755 & 798 & 749 \\
\hline & $1 / 2008$ & 1100 & 1126 & 1103 & 1120 & 1137 & 1118 & 837 & 885 & 831 \\
\hline & $2 / 2008$ & 1230 & 1265 & 1239 & 1250 & 1271 & 1251 & 916 & 967 & 910 \\
\hline \multirow{9}{*}{$\begin{array}{l}\text { Cumulated half-months in } \\
\text { out-of-labour-force } \\
\text { until end of }\end{array}$} & $2 / 2004$ & 0.48 & 0.39 & 0.44 & 0.33 & 0.31 & 0.23 & 1.29 & 1.25 & 1.32 \\
\hline & $1 / 2005$ & 1.09 & 0.90 & 1.05 & 0.76 & 0.65 & 0.59 & 3 & 2.84 & 3.08 \\
\hline & $2 / 2005$ & 1.73 & 1.40 & 1.68 & 1.24 & 1.05 & 0.96 & 4.98 & 4.80 & 5.12 \\
\hline & $1 / 2006$ & 2.41 & 1.93 & 2.31 & 1.74 & 1.48 & 1.38 & 7.27 & 7.09 & 7.47 \\
\hline & $2 / 2006$ & 3.12 & 2.50 & 3.01 & 2.31 & 2.01 & 1.89 & 10.01 & 9.78 & 10.19 \\
\hline & $1 / 2007$ & 3.88 & 3.11 & 3.79 & 2.99 & 2.65 & 2.55 & 13.23 & 12.98 & 13.44 \\
\hline & $2 / 2007$ & 4.69 & 3.79 & 4.63 & 3.77 & 3.37 & 3.23 & 16.90 & 16.63 & 17.10 \\
\hline & $1 / 2008$ & 5.56 & 4.53 & 5.50 & 4.64 & 4.26 & 3.99 & 21.07 & 20.84 & 21.30 \\
\hline & $2 / 2008$ & 6.47 & 5.29 & 6.38 & 5.57 & 5.29 & 4.83 & 25.80 & 25.47 & 25.85 \\
\hline \multirow{9}{*}{$\begin{array}{l}\text { Number of employer } \\
\text { changes until } \\
\text { end of }\end{array}$} & $2 / 2004$ & 0.00 & 0.00 & 0.00 & 0.00 & 0.00 & 0.00 & 0.00 & 0.00 & 0.00 \\
\hline & $1 / 2005$ & 0.01 & 0.01 & 0.01 & 0.01 & 0.00 & 0.00 & 0.00 & 0.00 & 0.00 \\
\hline & $2 / 2005$ & 0.03 & 0.03 & 0.01 & 0.02 & 0.01 & 0.01 & 0.02 & 0.01 & 0.01 \\
\hline & $1 / 2006$ & 0.05 & 0.04 & 0.03 & 0.03 & 0.03 & 0.02 & 0.03 & 0.02 & 0.01 \\
\hline & $2 / 2006$ & 0.09 & 0.06 & 0.04 & 0.08 & 0.04 & 0.03 & 0.05 & 0.03 & 0.03 \\
\hline & $1 / 2007$ & 0.12 & 0.08 & 0.05 & 0.10 & 0.06 & 0.04 & 0.06 & 0.03 & 0.03 \\
\hline & $2 / 2007$ & 0.16 & 0.11 & 0.07 & 0.13 & 0.08 & 0.06 & 0.08 & 0.04 & 0.04 \\
\hline & $1 / 2008$ & 0.19 & 0.14 & 0.08 & 0.15 & 0.11 & 0.07 & 0.09 & 0.06 & 0.05 \\
\hline & $2 / 2008$ & 0.22 & 0.19 & 0.10 & 0.17 & 0.14 & 0.08 & 0.11 & 0.08 & 0.07 \\
\hline \multirow{9}{*}{$\begin{array}{l}\text { Number of terminations } \\
\text { of employment due } \\
\text { to longer illness until } \\
\text { end of }\end{array}$} & $2 / 2004$ & 0.01 & 0.01 & 0.01 & 0.01 & 0.01 & 0.01 & 0.02 & 0.02 & 0.02 \\
\hline & $1 / 2005$ & 0.02 & 0.02 & 0.02 & 0.02 & 0.02 & 0.02 & 0.03 & 0.03 & 0.03 \\
\hline & 2/2005 & 0.03 & 0.04 & 0.03 & 0.03 & 0.03 & 0.03 & 0.05 & 0.06 & 0.05 \\
\hline & $1 / 2006$ & 0.04 & 0.05 & 0.05 & 0.05 & 0.05 & 0.05 & 0.07 & 0.07 & 0.07 \\
\hline & $2 / 2006$ & 0.05 & 0.06 & 0.06 & 0.06 & 0.06 & 0.06 & 0.08 & 0.09 & 0.09 \\
\hline & $1 / 2007$ & 0.07 & 0.07 & 0.07 & 0.08 & 0.07 & 0.08 & 0.09 & 0.11 & 0.10 \\
\hline & $2 / 2007$ & 0.08 & 0.08 & 0.08 & 0.09 & 0.09 & 0.09 & 0.11 & 0.13 & 0.12 \\
\hline & $1 / 2008$ & 0.09 & 0.09 & 0.09 & 0.11 & 0.11 & 0.11 & 0.12 & 0.14 & 0.13 \\
\hline & $2 / 2008$ & 0.10 & 0.10 & 0.11 & 0.12 & 0.12 & 0.13 & 0.14 & 0.15 & 0.14 \\
\hline \multicolumn{2}{|c|}{ \# of employees (observations) } & 6247 & 4858 & 3312 & 6613 & 4622 & 3420 & 4366 & 3073 & 2135 \\
\hline
\end{tabular}

Note: $1 / 200 x$ denotes the first half of the $200 x$, while $2 / 200 x$ denotes the second half of this year. 
Table A.3: Selection of variables determined prior to treatment

\begin{tabular}{|c|c|c|c|c|c|c|c|c|c|}
\hline \multirow{2}{*}{$\begin{array}{c}\text { Age in } 2002 \\
\text { Establishment health policy (treatment) }\end{array}$} & \multicolumn{3}{|c|}{31 to 40} & \multicolumn{3}{|c|}{41 to 50} & \multicolumn{3}{|c|}{ "51 to 60} \\
\hline & None & SickA & Cour & None & SickA & Cour & None & SickA & Cour \\
\hline Women (share) & 0.39 & 0.37 & 0.49 & 0.42 & 0.44 & 0.55 & 0.44 & 0.43 & 0.52 \\
\hline Age (in years) & 35.9 & 35.8 & 35.9 & 45.3 & 45.3 & 45.2 & 54.9 & 54.8 & 54.8 \\
\hline Foreigner (share) & 0.06 & 0.09 & 0.05 & 0.05 & 0.06 & 0.05 & 0.07 & 0.07 & 0.05 \\
\hline Half-monthly earnings in June $2002 / 1000$ & 1.26 & 1.27 & 1.26 & 1.30 & 1.30 & 1.28 & 1.29 & 1.33 & 1.24 \\
\hline Tenure in June 2002 in years & 2.56 & 2.51 & 2.62 & 2.90 & 2.83 & 3.05 & 3.07 & 3.09 & 3.27 \\
\hline Part-time employed (share) & 0.17 & 0.15 & 0.24 & 0.19 & 0.18 & 0.28 & 0.25 & 0.22 & 0.30 \\
\hline nal degree (share) & 0.16 & 0.17 & 0.09 & 0.22 & 0.18 & 0.12 & 0.22 & 0.18 & 0.15 \\
\hline polytechnical degree (share) & 0.08 & 0.08 & 0.09 & 0.08 & 0.07 & 0.08 & 0.06 & 0.07 & 0.05 \\
\hline Vocational degree missing (share) & 0.04 & 0.08 & 0.05 & 0.04 & 0.09 & 0.06 & 0.04 & 0.09 & 0.07 \\
\hline Occu & 0.10 & 0.22 & 0.10 & 0.11 & 0.20 & 0.09 & 0.09 & 0.17 & 0.07 \\
\hline lare) & 0.13 & 0.09 & 0.10 & 0.14 & 0.12 & 0.15 & 0.14 & 0.14 & 0.19 \\
\hline n (share) & 0.13 & 0.11 & 0.08 & 0.13 & 0.11 & 0.07 & 0.13 & 0.10 & 0.08 \\
\hline & 0.19 & 0.23 & 0.11 & 0.18 & 0.22 & 0.08 & 0.18 & 0.22 & 0.10 \\
\hline & 0.46 & 0.62 & 0.29 & 0.47 & 0.58 & 0.25 & 0.43 & 0.58 & 0.27 \\
\hline (share) & 0.20 & 0.14 & 0.13 & 0.18 & 0.14 & 0.13 & 0.23 & 0.14 & 0.17 \\
\hline loyed in past 10 years & 0.87 & 0.85 & 0.85 & 0.92 & 0.92 & 0.90 & 0.94 & 0.95 & 0.94 \\
\hline 10 year & 0.02 & 0.02 & 0.03 & 0.02 & 0.02 & 0.02 & 0.01 & 0.01 & 0.01 \\
\hline , ta & 0.02 & 0.02 & 0.02 & 0.01 & 0.0 & 0.01 & 0.01 & 0.01 & 0.01 \\
\hline Centra & 0.34 & 0.31 & 0.41 & 0.35 & 0.31 & 0.44 & 0.38 & 0.32 & 0.42 \\
\hline $5-64$ & 1.18 & 1.00 & 0.84 & 1.13 & 1.20 & 0.69 & 1.36 & 1.24 & 0.74 \\
\hline 994 & 0.23 & 0.22 & 0.19 & 0.24 & 0.22 & 0.19 & 0.23 & 0.22 & 0.19 \\
\hline stablishr & 301 & 304 & 361 & 304 & 301 & 372 & 298 & 310 & 364 \\
\hline Problems with high absenteeism & 0.13 & 0.09 & 0.10 & 0.13 & 0.11 & 0.10 & 0.11 & 0.10 & 0.09 \\
\hline are) & 0.35 & 0.39 & 044 & 0.33 & 0.3 & 0.46 & 0.33 & 0.38 & 0.51 \\
\hline & 0.75 & 0.68 & 0.35 & 0.77 & 0.72 & 0.33 & 0.74 & 0.65 & 0.30 \\
\hline No us & 0.52 & 0.52 & 0.40 & 0.51 & 0.52 & 0.39 & 0.48 & 0.54 & 0.37 \\
\hline Subje & 0.80 & 0.79 & 0.71 & 0.81 & 0.7 & 0.71 & 0.84 & 0.81 & 0.74 \\
\hline & 011 & 008 & م00 & 011 & 00 & 0.12 & 0.10 & 0.09 & 0.11 \\
\hline Firm & 0.07 & 0.15 & & 0.06 & 0.13 & 0.08 & 0.05 & 0.12 & 0.07 \\
\hline ect to general wage contract (share) & 0.02 & 0.07 & 0.01 & 0.02 & 0.07 & 0.01 & 0.02 & 0.05 & 0.01 \\
\hline & 0.80 & 0.86 & 0.89 & 0.84 & 0.87 & & 0.86 & 0.89 & 0.90 \\
\hline & 0.43 & $0.4 \varepsilon$ & 0.51 & $0 M$ & 0.5 & 0.52 & 0.42 & 0.46 & 0.49 \\
\hline uarter (sha & 0.28 & 0.25 & 0.15 & 0.24 & 0.23 & 0.11 & 0.27 & 0.28 & 0.13 \\
\hline Establ & 0.22 & 0.24 & 0.31 & 0.24 & 0.23 & 0.34 & 0.24 & 0.24 & 0.34 \\
\hline $\begin{array}{l}\text { Share of determinations of employment } \\
\text { contracts due to longer illness in past } 10 \mathrm{y} \text {. }\end{array}$ & 0.17 & 0.17 & 0.18 & 0.17 & 0.17 & 0.19 & 0.17 & 0.17 & 0.18 \\
\hline
\end{tabular}

Note: Based on the samples used for estimation. If not explicitly mentioned otherwise, variables are measured in 2002.

\section{Appendix B: Additional results}

\section{B.1 Propensity scores}

In this section, we show the detailed specification and estimation results for the propensity scores used in the estimation. 
Table B.1: Probit estimation results for the probability to be treated

\begin{tabular}{|c|c|c|c|c|c|c|c|c|c|c|c|c|}
\hline \multirow{3}{*}{$\begin{array}{l}\text { Treatment } \\
\text { Startum }\end{array}$} & \multicolumn{6}{|c|}{ Analysis of sickness absenteeism } & \multicolumn{6}{|c|}{ Health circles/courses } \\
\hline & \multicolumn{2}{|c|}{$31-40$} & \multicolumn{2}{|c|}{$41-50$} & \multicolumn{2}{|c|}{$51-60$} & \multicolumn{2}{|c|}{$31-40$} & \multicolumn{2}{|c|}{$41-50$} & \multicolumn{2}{|c|}{$51-60$} \\
\hline & Coeff. & $\mathrm{p}$-val. & Coeff. & $\mathrm{p}$-val. & Coeff. & $\mathrm{p}$-val. & Coeff. & $\mathrm{p}$-val. & Coeff. & $\mathrm{p}$-val. & Coeff. & p-val. \\
\hline Women & 0.15 & 0.0 & 0.22 & 0.0 & 0.22 & 0.0 & 0.08 & 3.0 & 0.13 & 0.0 & 0.05 & 28.3 \\
\hline Age & -0.01 & 25.8 & 0.01 & 62.4 & 0.01 & 78.5 & -0.01 & 17.1 & -0.02 & 0.1 & 0.01 & 50.5 \\
\hline Foreigner & 0.17 & 0.1 & 0.03 & 57.9 & -0.08 & 18.9 & 0.02 & 80.9 & -- & & -0.15 & 4.6 \\
\hline Earnings & 0.18 & 0.0 & 0.16 & 0.0 & 0.13 & 0.3 & 0.21 & 0.0 & 0.18 & 0.0 & -0.05 & 35.3 \\
\hline Tenure in months & -0.02 & 18.3 & -0.03 & 1.8 & -0.03 & 21.4 & 0.03 & 16.0 & 0.05 & 0.1 & 0.12 & 0.0 \\
\hline Part time employ. & 0.05 & 28.8 & 0.05 & 16.5 & 0.02 & 60.5 & 0.04 & 30.3 & 0.12 & 0.5 & -0.07 & 15.3 \\
\hline No vocat. degree & -0.08 & 5.9 & -0.22 & 0.0 & -0.22 & 0.0 & -0.28 & 0.0 & -0.28 & 0.0 & -0.27 & 0.0 \\
\hline University/polytech. & -0.08 & 14.1 & -0.09 & 5.7 & 0.08 & 18.7 & 0.04 & 45.9 & 0.01 & 84.7 & -0.04 & 65.2 \\
\hline Voc. degree missing & 0.70 & 0.0 & 0.70 & 0.0 & 0.69 & 0.0 & 0.17 & 2.4 & 0.16 & 1.4 & 0.30 & 0.0 \\
\hline Occ. in manufact. & 0.41 & 0.0 & 0.44 & 0.0 & 0.41 & 0.0 & 0.22 & 0.1 & 0.19 & 0.2 & 0.13 & 10.3 \\
\hline $\begin{array}{l}\text { Low skilled service } \\
\text { occupation }\end{array}$ & -0.15 & 0.2 & 0.06 & 18.6 & 0.12 & 3.2 & -0.13 & 1.0 & 0.03 & 50.5 & 0.17 & 0.5 \\
\hline Occ. in construction & -0.11 & 1.7 & 0.05 & 28.7 & -0.01 & 81.1 & -0.26 & 0.0 & -0.15 & 0.7 & -0.23 & 0.1 \\
\hline Technical occupat. & 0.21 & 0.0 & 0.33 & 0.0 & 0.17 & 0.0 & -0.16 & 0.2 & -0.15 & 0.3 & -0.19 & 0.2 \\
\hline Share UE last $10 \mathrm{y}$. & 0.51 & 0.8 & 0.86 & 0.0 & 0.42 & 23.2 & -- & & -- & & -- & \\
\hline Share inactive ... & 0.57 & 25.6 & 0.27 & 65.6 & 0.69 & 43.9 & -- & & -- & & -- & \\
\hline Share employed... & -0.36 & 0.0 & -0.16 & 12.6 & 0.03 & 84.0 & -0.48 & 0.0 & -- & & -0.07 & 67.6 \\
\hline Northern states & -0.21 & 0.0 & -0.34 & 0.0 & -0.30 & 0.0 & -- & & -- & & -- & \\
\hline Central states & -0.29 & 0.0 & -0.37 & 0.0 & -0.40 & 0.0 & -0.20 & 0.0 & -0.12 & 0.0 & -0.21 & 0.0 \\
\hline Jobs per inhabitant & 0.0 & 0.0 & 0.0 & 0.4 & 0.0 & 0.0 & 00 & 0.0 & 0.0 & 0.0 & 0.0 & 0.0 \\
\hline Reg. GDP growth & -2.01 & 0.0 & -1.61 & 0.0 & -2.06 & 0.0 & -2.36 & 0.0 & -2.41 & 0.0 & -3.08 & 0.0 \\
\hline Manufact. (sector) & 0.33 & 0.0 & 0.34 & 0.0 & 0.43 & 0.0 & -0.46 & 0.0 & -0.43 & 0.0 & -0.22 & 0.0 \\
\hline Construction, trade & 0.15 & 0.0 & 0.13 & 0.1 & 0.01 & 86.7 & -0.32 & 1.8 & -0.36 & 0.0 & -0.21 & 0.0 \\
\hline Age of establish. & 0.01 & 0.0 & 0.02 & 0.0 & 0.02 & 0.0 & 0.01 & 0.0 & -- & 0.0 & 0.01 & 0.3 \\
\hline \# of employees (In) & 0.04 & 12.4 & 0.05 & 3.7 & 0.12 & 0.1 & 0.29 & 0.0 & 0.43 & 0.0 & 0.39 & 0.0 \\
\hline Hiring difficulties & 0.19 & 0.0 & 0.17 & 0.0 & 0.22 & 0.0 & 0.50 & 0.0 & 0.59 & 0.0 & 0.77 & 0.0 \\
\hline $\begin{array}{l}\text { Sect. wage contract } \\
\& \text { many absences }\end{array}$ & -0.45 & 0.0 & -0.50 & 0.0 & -0.57 & 0.0 & -0.37 & 0.0 & -0.26 & 0.0 & -0.34 & 0.0 \\
\hline Work council & 0.44 & 0.0 & 0.42 & 0.0 & 0.53 & 0.0 & 0.28 & 0.0 & -- & 1.8 & 0.45 & 0.0 \\
\hline $\begin{array}{l}\text { Firm with single } \\
\text { establishment }\end{array}$ & 0.12 & 0.0 & 0.24 & 0.0 & 0.13 & 0.0 & 0.32 & 0.0 & 0.34 & 0.0 & 0.39 & 0.0 \\
\hline $\begin{array}{l}\text { Investment per } \\
\text { employee / } 10000\end{array}$ & -0.02 & 5.6 & 0.01 & 75.7 & -0.02 & 20.8 & -0.42 & 46.9 & -0.21 & 0.0 & -0.29 & 0.0 \\
\hline No use of subsidies & 0.14 & 0.0 & 0.07 & 0.9 & 0.27 & 0.0 & -0.02 & 0.0 & -0.07 & & 0.04 & 28.2 \\
\hline Work. time accounts & 0.40 & 0.0 & -- & & -- & & 0.70 & 0.0 & -- & & -- & \\
\hline $\begin{array}{l}\text { Share of termina- } \\
\text { tions of employment } \\
\text { contracts due to } \\
\text { longer illness past } \\
10 \mathrm{y} \text {. }\end{array}$ & 0.89 & 0.2 & 1.07 & 0.0 & 0.95 & 1.1 & 0.75 & 2.0 & -- & & 1.19 & 0.2 \\
\hline$<0.15$ & -- & & -- & & -- & & -- & & -0.45 & 0.0 & -- & \\
\hline$>0.2$ & -- & & -- & & -- & & -- & & -0.19 & 0.0 & -- & \\
\hline Pseudo-R² in \% & & 14.1 & & 11.5 & & 13.7 & & 23.8 & & 22.2 & & 24.1 \\
\hline \# of unique establishn & nents & 197 & & 196 & & 197 & & 163 & & 162 & & 163 \\
\hline te: $\quad--:$ V & 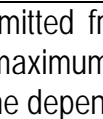 & 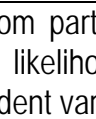 & 1 & al & 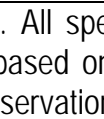 & & incl & & & & & \\
\hline
\end{tabular}




\section{B.2 Average treatment effects for the non-treated}

As already mentioned in the main text (see Section 5.2), one way to assess potential effect heterogeneity is to compare the average effects for workers in establishments without any health promotion measure to the average effects for all workers. The reason is that non-treated firms and their employees differ systematically from the average firm and its employees. Here we present the results for workers in non-treated firms (which are very similar to the average effects).

Table B.2: Average effects on tenure in the original establishment in days

\begin{tabular}{lccc}
\hline \hline Health promotion measure & Age & Effect & P-value in \% \\
\hline Analysis of sickness absen- & $31-40$ & 85 & 26 \\
teeism & $41-50$ & 40 & 55 \\
& $51-60$ & 87 & 25 \\
\hline Health circles/courses & $31-40$ & $200^{\star \star \star}$ & 1 \\
& $41-50$ & $157^{\star \star}$ & 4 \\
& $51-60$ & $185^{\star \star \star}$ & 0 \\
\hline
\end{tabular}

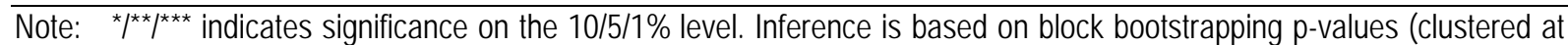
the establishment level, 499 replications). Tenure refers to the time with the establishment after treatment measured from July 2004. Tenure before that is a control variable.

Figure B.1: Average effects on the number of employer changes
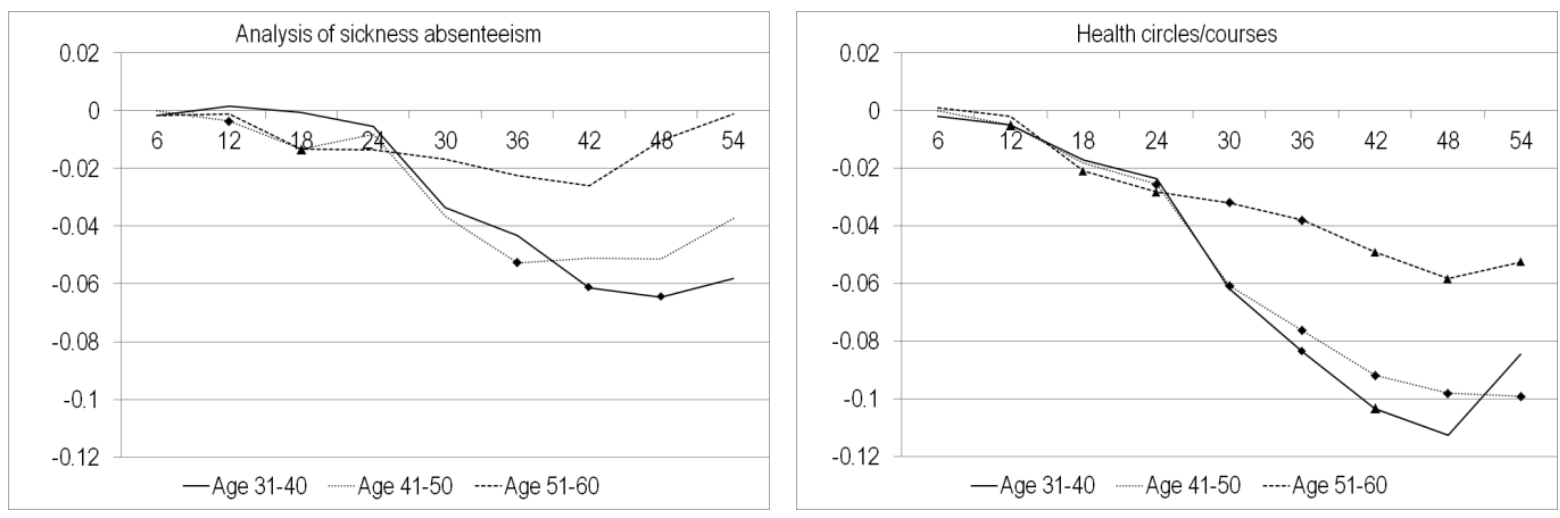

Note: Lines denote average treatment effects on the for respective age stratum. The symbol ' $\boldsymbol{\Lambda}$ ' denotes significance at the $5 \%$ level, while ' ' denotes significance at the $10 \%$ level. The horizontal axis measures the number of months since June 2004 (half-yearly measurements in June and December of each year). Inference is based on block bootstrapping p-values (clustered at the establishment level, 499 replications). 
Figure B.2: Average effects on cumulated unsubsidised employment in months
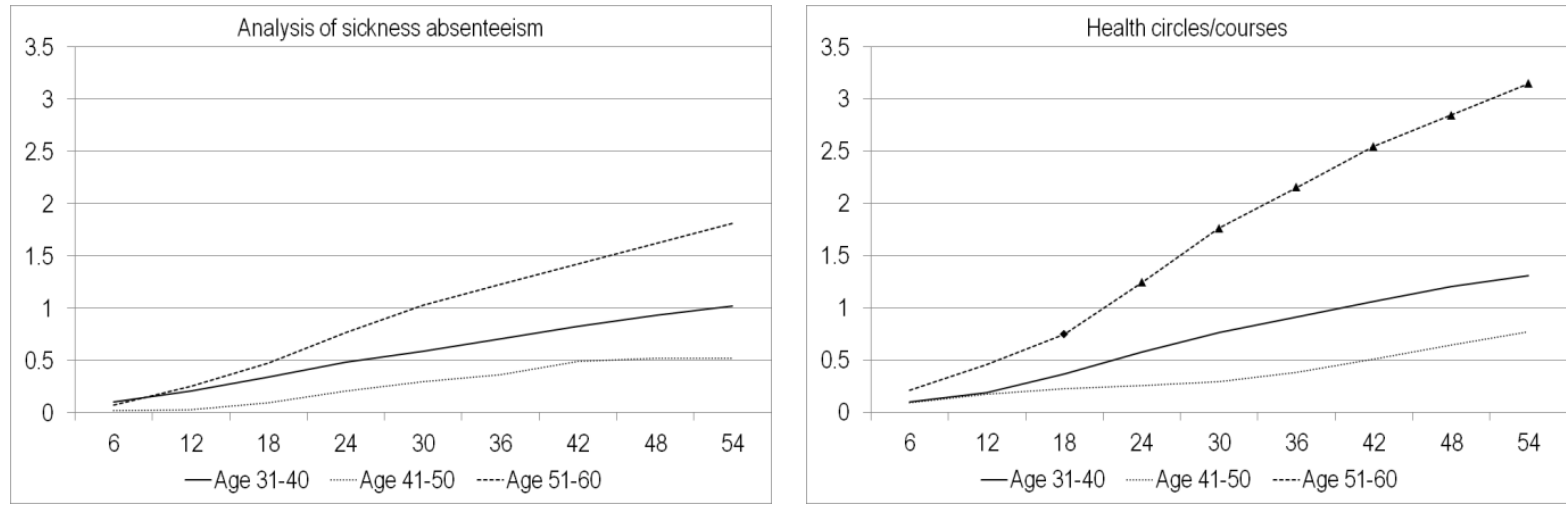

Note: See note to Figure B.1.

Figure B.3: Average effects on cumulated unemployment in months
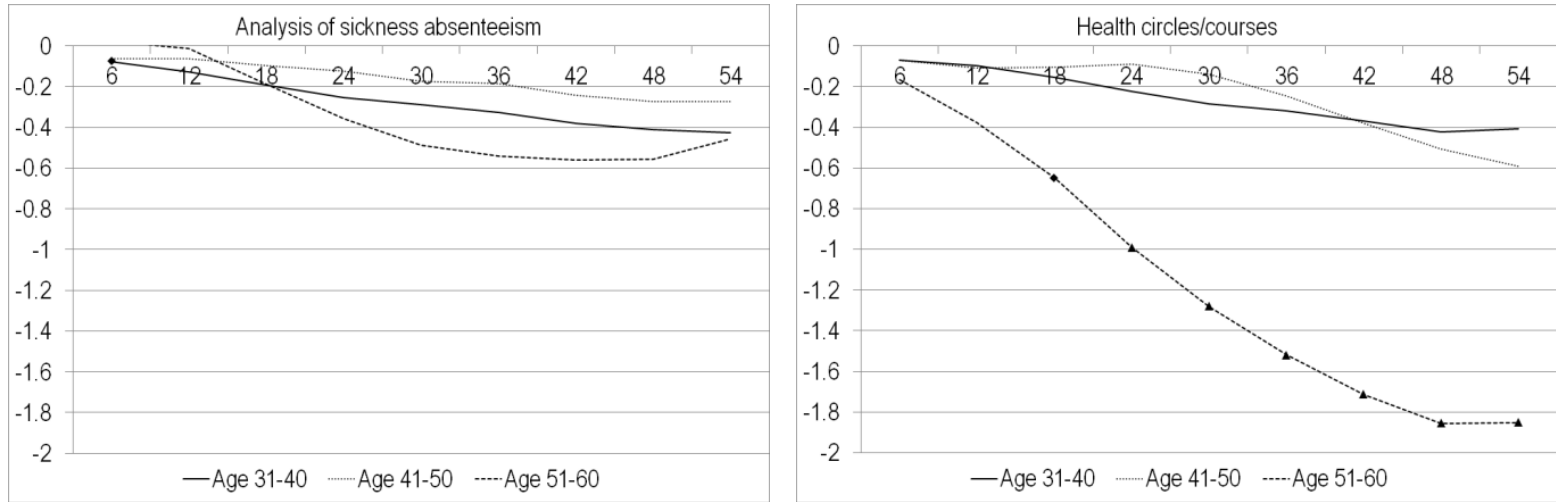

Note: See note to Figure B.1.

Figure B.4: Average effects on months in firm-provided early retirement scheme
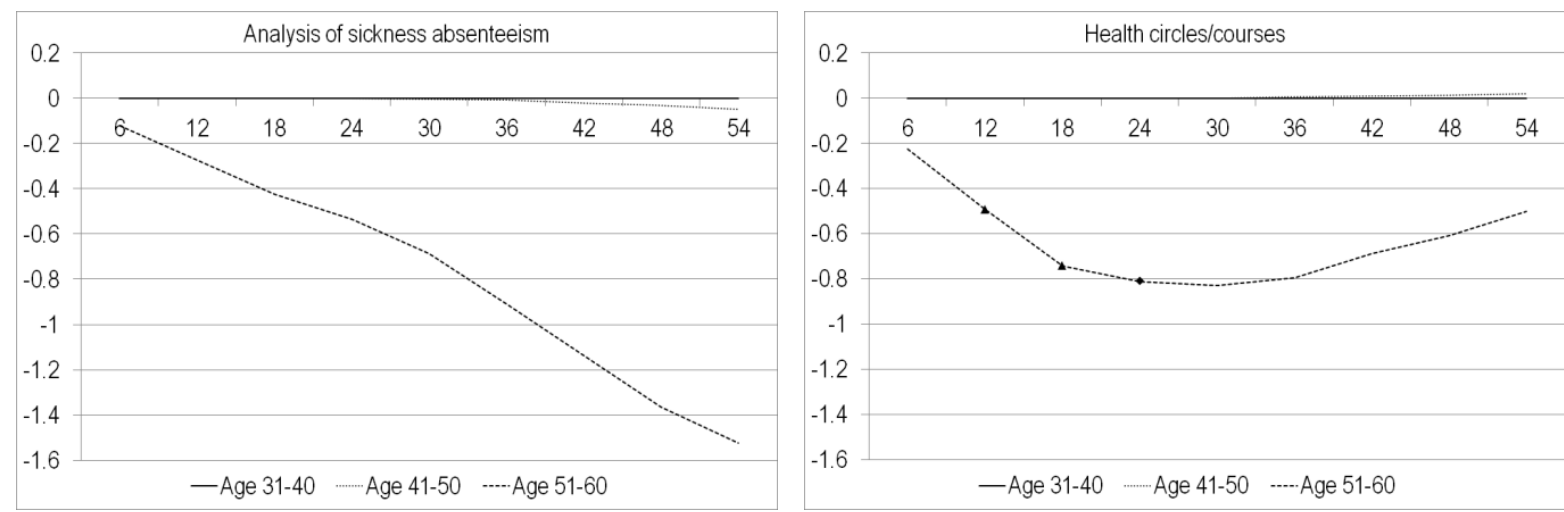

Note: See note to Figure B.1. 


\section{B.3 Point-in-time estimates}

Table B.3: Effects of analysing sickness absenteeism on the probability to be in a certain labour market state in percentage points

\begin{tabular}{|c|c|c|c|c|c|c|c|c|c|c|c|}
\hline & & \multicolumn{4}{|c|}{ Age $31-40$} & \multicolumn{2}{|c|}{ Age 41-50 } & & \multicolumn{3}{|c|}{ Age 51-60 } \\
\hline & & ATEN & & ATE & & ATENT & ATE & & ATENT & ATE & \\
\hline \multirow[t]{9}{*}{ Employed end of } & $2 / 2004$ & 0.016 & & 0.011 & & -0.010 & -0.003 & & 0.019 & 0.009 & \\
\hline & $1 / 2005$ & 0.020 & & 0.013 & & 0.013 & 0.011 & & 0.031 & 0.020 & \\
\hline & $2 / 2005$ & 0.021 & & 0.015 & & 0.017 & 0.011 & & 0.039 & 0.018 & \\
\hline & $1 / 2006$ & 0.021 & & 0.018 & & 0.022 & 0.013 & & 0.033 & 0.009 & \\
\hline & $2 / 2006$ & 0.019 & & 0.018 & & 0.004 & 0.001 & & 0.043 & 0.015 & \\
\hline & $1 / 2007$ & 0.018 & & 0.016 & & 0.018 & 0.012 & & 0.035 & 0.013 & \\
\hline & $2 / 2007$ & 0.017 & & 0.011 & & 0.016 & 0.011 & & 0.030 & 0.008 & \\
\hline & $1 / 2008$ & 0.015 & & 0.013 & & 0.000 & -0.005 & & 0.035 & 0.006 & \\
\hline & $2 / 2008$ & 0.012 & & 0.006 & & 0.000 & -0.005 & & 0.031 & 0.006 & \\
\hline \multirow{9}{*}{$\begin{array}{l}\text { In early retirement } \\
\text { scheme end of }\end{array}$} & $2 / 2004$ & 0.000 & & 0.000 & & 0.000 & 0.000 & & -0.023 & -0.016 & \\
\hline & $1 / 2005$ & 0.000 & & 0.000 & & 0.000 & 0.000 & & -0.026 & -0.018 & \\
\hline & $2 / 2005$ & 0.000 & & 0.000 & & 0.000 & 0.000 & & -0.025 & -0.018 & \\
\hline & $1 / 2006$ & 0.000 & & 0.000 & & 0.000 & 0.000 & & -0.021 & -0.017 & \\
\hline & $2 / 2006$ & 0.000 & & 0.000 & & 0.002 & 0.001 & & -0.028 & -0.022 & \\
\hline & $1 / 2007$ & 0.000 & & 0.000 & & -0.001 & -0.001 & & -0.041 & -0.033 & * \\
\hline & $2 / 2007$ & 0.000 & & 0.000 & & -0.002 & -0.002 & & -0.036 & -0.029 & \\
\hline & $1 / 2008$ & 0.000 & & 0.000 & & -0.002 & -0.002 & & -0.039 & -0.031 & * \\
\hline & $2 / 2008$ & 0.000 & & 0.000 & & -0.005 & -0.004 & * & -0.027 & -0.025 & \\
\hline \multirow{9}{*}{$\begin{array}{l}\text { Unemployed } \\
\text { end of }\end{array}$} & $2 / 2004$ & -0.010 & & -0.006 & & -0.001 & -0.004 & & 0.002 & -0.001 & \\
\hline & $1 / 2005$ & -0.008 & & -0.001 & & -0.003 & -0.004 & & -0.017 & -0.016 & \\
\hline & $2 / 2005$ & -0.013 & & -0.006 & & -0.011 & -0.008 & & -0.035 & * $\quad-0.026$ & * \\
\hline & $1 / 2006$ & -0.006 & & -0.002 & & -0.012 & -0.007 & & -0.018 & -0.007 & \\
\hline & $2 / 2006$ & -0.005 & & -0.004 & & 0.003 & 0.001 & & -0.023 & -0.011 & \\
\hline & $1 / 2007$ & -0.011 & * & -0.009 & & -0.007 & -0.004 & & -0.006 & -0.003 & \\
\hline & $2 / 2007$ & -0.003 & & -0.003 & & -0.003 & -0.007 & & 0.001 & 0.000 & \\
\hline & $1 / 2008$ & -0.004 & & -0.004 & & -0.004 & -0.004 & & 0.010 & 0.004 & \\
\hline & $2 / 2008$ & -0.002 & & -0.001 & & 0.012 & 0.007 & & 0.001 & 0.002 & \\
\hline \multirow{9}{*}{$\begin{array}{l}\text { On unemployment } \\
\text { insurance end of }\end{array}$} & $2 / 2004$ & -0.007 & & -0.004 & & 0.004 & 0.000 & & 0.004 & 0.000 & \\
\hline & $1 / 2005$ & -0.008 & $\star *$ & -0.004 & & -0.004 & -0.006 & & -0.013 & -0.013 & \\
\hline & $2 / 2005$ & -0.004 & & -0.002 & & -0.011 & -0.008 & & -0.027 & -0.021 & \\
\hline & $1 / 2006$ & -0.005 & & -0.003 & & -0.008 & -0.004 & & -0.015 & -0.005 & \\
\hline & $2 / 2006$ & -0.001 & & 0.002 & & 0.008 & 0.004 & & -0.016 & -0.006 & \\
\hline & $1 / 2007$ & -0.008 & $\star \star \star ~$ & -0.007 & $\star \star$ & -0.005 & -0.002 & & -0.001 & 0.002 & \\
\hline & $2 / 2007$ & -0.003 & & -0.005 & & -0.002 & -0.009 & & 0.005 & 0.002 & \\
\hline & $1 / 2008$ & -0.004 & & -0.005 & & -0.006 & -0.007 & & -0.006 & -0.004 & \\
\hline & $2 / 2008$ & 0.000 & & 0.001 & & 0.010 & 0.006 & & 0.002 & 0.001 & \\
\hline
\end{tabular}

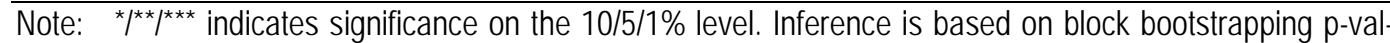
ues (clustered at the establishment level, 499 replications). 
Table B.4: Effects of health circles/courses on the probability to be in a certain labour market state in percentage points

\begin{tabular}{|c|c|c|c|c|c|c|c|c|c|c|}
\hline \multirow{3}{*}{ Employed end of } & \multirow[b]{3}{*}{$2 / 2004$} & \multicolumn{2}{|c|}{ Age $31-40$} & \multicolumn{2}{|c|}{ Age $41-50$} & & \multicolumn{4}{|c|}{ Age $51-60$} \\
\hline & & \multirow{2}{*}{$\begin{array}{c}\text { ATENT } \\
0.019\end{array}$} & \multirow{2}{*}{$\begin{array}{r}\text { ATE } \\
0.015\end{array}$} & \multirow{2}{*}{$\begin{array}{c}\text { ATENT } \\
0.011\end{array}$} & \multirow{2}{*}{\multicolumn{2}{|c|}{$\begin{array}{c}\text { ATE } \\
0.009\end{array}$}} & \multicolumn{2}{|c|}{ ATENT } & \multicolumn{2}{|l|}{ ATE } \\
\hline & & & & & & & 0.037 & & 0.044 & * \\
\hline & $1 / 2005$ & 0.019 & 0.015 & 0.005 & -0.001 & & 0.037 & & 0.039 & * \\
\hline & $2 / 2005$ & 0.029 & 0.021 & 0.002 & 0.001 & & 0.058 & * & 0.051 & ** \\
\hline & $1 / 2006$ & 0.027 & 0.018 & -0.003 & -0.008 & & 0.084 & $\star \star \star ~$ & 0.071 & $\star \star$ \\
\hline & $2 / 2006$ & $0.034 *$ & 0.023 & 0.013 & 0.005 & & 0.079 & ** & 0.064 & * \\
\hline & $1 / 2007$ & 0.014 & 0.004 & 0.013 & 0.004 & & 0.069 & ** & 0.055 & * \\
\hline & $2 / 2007$ & 0.024 & 0.019 & 0.019 & 0.009 & & 0.064 & ** & 0.048 & * \\
\hline & $1 / 2008$ & 0.014 & 0.006 & 0.019 & 0.010 & & 0.049 & * & 0.037 & \\
\hline & $2 / 2008$ & 0.014 & 0.006 & 0.023 & 0.014 & & 0.055 & * & 0.046 & \\
\hline In early retirement & $2 / 2004$ & 0.000 & 0.000 & 0.000 & 0.000 & & -0.035 & & -0.034 & \\
\hline \multirow[t]{8}{*}{ scheme end of } & $1 / 2005$ & 0.000 & 0.000 & 0.000 & 0.000 & & -0.044 & * & -0.037 & * \\
\hline & $2 / 2005$ & 0.000 & 0.000 & 0.000 & 0.000 & & -0.036 & & -0.030 & \\
\hline & $1 / 2006$ & 0.000 & 0.000 & 0.000 & 0.000 & & -0.005 & & 0.000 & \\
\hline & $2 / 2006$ & 0.000 & 0.000 & 0.007 & 0.005 & & 0.006 & & 0.007 & \\
\hline & $1 / 2007$ & 0.000 & 0.000 & 0.005 & 0.003 & & 0.015 & & 0.013 & \\
\hline & $2 / 2007$ & 0.000 & 0.000 & 0.003 & 0.002 & & 0.026 & & 0.025 & \\
\hline & $1 / 2008$ & 0.000 & 0.000 & 0.002 & 0.001 & & 0.019 & & 0.022 & \\
\hline & $2 / 2008$ & 0.000 & 0.000 & 0.004 & 0.003 & & 0.021 & & 0.024 & \\
\hline Unemployed & $2 / 2004$ & -0.011 & -0.010 & -0.015 & -0.010 & & -0.024 & & -0.026 & \\
\hline \multirow[t]{8}{*}{ end of } & $1 / 2005$ & -0.003 & -0.003 & 0.007 & 0.009 & & -0.036 & * & -0.033 & * \\
\hline & $2 / 2005$ & -0.014 & -0.011 & 0.001 & 0.003 & & -0.058 & $\star \star$ & -0.047 & 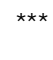 \\
\hline & $1 / 2006$ & -0.005 & -0.002 & 0.003 & 0.005 & & -0.052 & $\star *$ & -0.039 & $\star *$ \\
\hline & $2 / 2006$ & -0.013 & -0.008 & -0.005 & 0.000 & & -0.040 & * & -0.024 & \\
\hline & $1 / 2007$ & -0.002 & 0.000 & -0.015 & * $\quad-0.007$ & & -0.038 & * & -0.022 & \\
\hline & $2 / 2007$ & -0.007 & -0.013 & -0.015 & * $\quad-0.007$ & & -0.013 & & -0.006 & \\
\hline & $1 / 2008$ & 0.005 & 0.003 & -0.011 & -0.005 & & -0.008 & & -0.001 & \\
\hline & $2 / 2008$ & 0.007 & 0.004 & -0.009 & -0.004 & & 0.019 & & 0.015 & \\
\hline On unemployment & $2 / 2004$ & -0.005 & -0.005 & -0.008 & -0.005 & & -0.031 & * & -0.030 & * \\
\hline \multirow[t]{8}{*}{ insurance end of } & $1 / 2005$ & 0.003 & 0.002 & 0.011 & 0.012 & & -0.029 & & -0.026 & \\
\hline & $2 / 2005$ & -0.003 & -0.003 & 0.001 & 0.003 & & -0.048 & $* *$ & -0.039 & ** \\
\hline & $1 / 2006$ & -0.006 & -0.004 & 0.007 & 0.006 & & -0.047 & $\star \star$ & -0.036 & ** \\
\hline & $2 / 2006$ & $-0.007 *$ & * -0.004 & -0.005 & -0.002 & & -0.037 & $\star *$ & -0.022 & \\
\hline & $1 / 2007$ & -0.001 & -0.001 & -0.013 & ** $\quad-0.008$ & * & -0.037 & $\star *$ & -0.023 & \\
\hline & $2 / 2007$ & -0.009 & -0.024 & -0.017 & ** $\quad-0.010$ & ** & -0.019 & & -0.010 & \\
\hline & $1 / 2008$ & 0.002 & 0.001 & -0.012 & * $\quad-0.008$ & * & -0.018 & & -0.008 & \\
\hline & $2 / 2008$ & 0.007 & 0.003 & -0.005 & -0.003 & & 0.005 & & 0.004 & \\
\hline
\end{tabular}




\section{Appendix C: More details on the definition of the treatment}

Figure C. 1: Cut-and-paste from the original questionnaire

87. Welche Maßnahmen zum Schutz oder zur Förderung der Gesundheit der Beschäftigten, die über die gesetzlichen Regelungen hinausgehen, werden in Ihrem Betrieb/Ihrer Dienststelle durchgeführt oder finanziell unterstützt? Sagen Sie mir bitte, was von dieser Liste zutrifft.

Interv.: Liste 17 vorlegen und alles Zutreffende ankreuzen!
A Krankenstandsanalysen
B Mitarbeiterbefragungen zum Gesundheitsschutz am Arbeitsplatz
C Gesprächskreise zu gesundheitlichen Problemen im Betrieb („Gesundheitszirkel")
D Kurse zum gesundheitsgerechten Verhalten
E Sonstiges, und zwar:
F Nichts davon

Translation: "Beyond what is required by law, which measures to protect and improve the health of your employees are you implementing or supporting financially? Please indicate in the following list which items are true for your establishment.
A. Analysis of sick leave
B. Surveys of employees about health risks at the workplace
C. Discussion groups about health problems in the establishment (health circles)
D. Courses with information about healthy behaviour
E. Other, in particular: < fill in >
F. None of the above"

Note that indicating multiple measures is possible. The first treatment (SickAna) used in the main body of the paper consists of workers in those establishments indicating ' $A$ ', the second one consists of workers in establishments indicating ' $C$ ' and/or ' $D$ ' (Course). In either case, the control group consists of those establishments indicating option ' $\mathrm{F}$ ' (only). 